A N N A L ES

UNIVERSITATIS MARIAE CURIE-SKŁODOWSKA

LUBLIN - POLONIA

VOL. LXIII, 2

SECTIO G

2016

Uniwersytet Marii Curie-Skłodowskiej w Lublinie

grzegorz.lawnikowicz@poczta.umcs.lublin.pl

slawomir.pilipiec@poczta.umcs.lublin.pl

GRZEGORZ ŁAWNIKOWICZ, SŁAWOMIR PILIPIEC

\title{
Nieskazitelność charakteru i nieposzlakowana opinia w prawie prawniczych samorządów zawodowych
}

Impeccable Character and Good Repute in the Law

of Legal Professional Self-governing Bodies

\section{WPROWADZENIE}

W tytule artykułu użyto zwrotu „prawo prawniczych samorządów zawodowych". Autorzy mieli wątpliwości co do nomenklatury, gdyż w szeroko rozumianym dyskursie spotkać można również określenie „prawo korporacyjne”. Ostatecznie, nie negując walorów tego terminu, w szczególności cechującej go syntetyczności, mając jednak na względzie jego wieloznaczność, zdecydowali się na użycie tytułowego określenia. W naszym odczuciu w sposób niebudzący zasadniczych wątpliwości wskazuje ono na obszar i przedmiot analizy.

Zmierzać będziemy do odkodowania treści łączonych z pojęciami „nieskazitelność charakteru” i ,nieposzlakowana opinia”. Skoncentrujemy się na ustaleniu odpowiedzi na kilka szczegółowych pytań, zwłaszcza: czy treść powinności jest różna w zależności od profesji, do której jest adresowany wymóg oraz jakie jest usytuowanie klauzul w systemie danej profesji i jak ta pozycja, a tym samym relacje $\mathrm{z}$ innymi powinnościami, na ogół także ujętymi w formę klauzul, wpływa na znaczenie przypisywane nieskazitelności charakteru i nieposzlakowanej opinii. $\mathrm{Z}$ przedmiotowego punktu widzenia drugie z zagadnień, obejmując również analizę złożonego obszaru relacji między normami ustawowymi a „kodeksowymi” i ,pozakodeksowymi” normami deontologii zawodowej, skłania do sformułowania pytania o rolę wskazanych norm w dookreśleniu tytułowych klauzul ${ }^{1}$.

1 Używając określeń „kodeksowe” i „pozakodeksowe” mamy na myśli normy deontologii zawodowej, zarówno te zawarte w kodeksach etyki zawodowej, jak i te, które są obecne w niepisanym etosie zawodu. 
Nasze poszukiwania mają autonomiczny charakter, łączy je cel, a w zasadzie cele wskazane wyżej. Kryterium podziału rozważań stanowią zainteresowania naukowe autorów, ale nie tylko, ponieważ sama potrzeba wyróżnienia dwóch obszarów badań wiąże się ze specyfiką prawniczych profesji, z faktem, że z jednej strony wykonują je funkcjonariusze publiczni, a z drugiej ci, którzy tego statusu nie posiadają. W naszym przekonaniu jest to nie tylko zasadnicze kryterium podziału, ale też źródło dodatkowego pytania. Brzmi ono: czy ten status, względnie jego brak, wpływa na postrzeganie tytułowych klauzul?

Nie mamy możliwości równomiernego i sumiennego przedstawienia wszystkich zagadnień. $Z$ góry przyjęliśmy, że będziemy stawiali tezy, sukcesywnie formułowali wnioski, sygnalizowali problemy oraz nieco szerzej analizowali te z nich, które w naszej subiektywnej opinii zasługują na szczególne uznanie. To zaważy na formie, która musi być skrótowa. Artykuł dzieli się na dwie części. Autorem pierwszej jest G. Ławnikowicz, drugiej zaś S. Pilipiec. Poświęcono je odpowiednio funkcjonariuszom publicznym (jak sędziowie, prokuratorzy, notariusze i komornicy) oraz adwokatom i radcom prawnym.

\section{FUNKCJONARIUSZE PUBLICZNI}

Nieskazitelność charakteru stanowi jeden z wymogów stawianych przed kandydatami na każde stanowisko sędziowskie (w sądach powszechnych, administracyjnych, wojskowych, Sądzie Najwyższym), nadto na stanowiska: prokuratora, notariusza, radcy Prokuratorii Generalnej, referendarza, asesorów i aplikantów (sędziowskiego, prokuratorskiego, notarialnego) oraz ławników² ${ }^{2}$ Racjonalne będzie przyjęcie a fortiori, że nieskazitelnością charakteru powinni się wykazywać ci, którzy piastują wymienione stanowiska.

Wymóg posiadania nieposzlakowanej opinii stawia się przed osobami ubiegającymi się o powołanie na stanowisko komornika oraz aplikanta i asesora komorniczego ${ }^{3}$. W tym wypadku także, wnioskując a fortiori, należy uznać, że nieposzlakowaną opinią muszą się wykazywać również ci, którzy już są komornikami.

2 Patrz w szczególności: art. $61 \S 1$ pkt 2, art. $149 \S 1$ pkt 2, art. $155 \S 1$ pkt 2, art. $158 \S 1$ pkt 2 ustawy z dnia 27 lipca 2001 r. - Prawo o ustroju sądów powszechnych (Dz.U. z 2001 r., nr 98, poz. 1070 z późn. zm.), dalej jako: prawo o u.s.p.; art. 22 § 1 ust. 2 ustawy z dnia 23 listopada 2002 r. o Sądzie Najwyższym (t.j. Dz.U. z 2013 r., poz. 499); art. 6 § 1 pkt 2 ustawy z dnia 25 lipca 2002 r. - Prawo o ustroju sądów administracyjnych (t.j. Dz.U. z 2014 r., poz. 1647); art. 22 § 1 pkt 2, art. 55 § 1 ustawy z dnia 21 sierpnia 1997 r. - Prawo o ustroju sądów wojskowych (Dz.U. z 2015 r., poz. 1198); art. 14 ust. 1 pkt 2, art. 100 ust. $1 \mathrm{w}$ zw. z art. 14 ust. 1 pkt 2, art. 100a ust. 5 pkt 2 ustawy z dnia 20 czerwca 1985 r. o prokuraturze (t.j. Dz.U. z 2002 r., nr 21, poz. 206); art. 29 ust. 1 pkt 6 ustawy z dnia 8 lipca 2005 r. o Prokuratorii Generalnej Skarbu Państwa (t.j. Dz.U. z 2013 r., poz. 1150); art. 11 pkt 2 ustawy z dnia 14 lutego 1991 r. - Prawo o notariacie (t.j. Dz.U. z 2014 r., poz. 164).

3 Zob. art. 10 ust. 1 pkt 3. ustawy z dnia 29 sierpnia 1997 r. o komornikach sądowych i egzekucji (t.j. Dz.U. z 2015 r., poz. 790), dalej jako: u.k.s.e. 
Wskazane założenie zostało przyjęte w wyniku nowelizacji ustawy o komornikach sądowych i egzekucji, której dokonano ustawą z dnia 24 maja 2007 r. Do tej pory zatem także komornicy (przyszli komornicy) musieli wykazywać się nieskazitelnym charakterem ${ }^{4}$. Tym samym postawiono ich $\mathrm{w}$ jednym rzędzie między innymi z policjantami, członkami korpusu służby cywilnej, pracownikami samorządowymi zatrudnionymi na podstawie umowy o pracę czy pracownikami sądów i prokuratury5.

Analizę pojęcia „nieposzlakowana opinia” przeprowadzę w dalszej części artykułu, bezpośrednio po ustaleniu treści wiązanych z „nieskazitelnym charakterem". Zestawienie wyniku badań poświęconych nieskazitelności z wymogiem stawianym przed komornikami pozwoli na pełniejsze zrozumienie obydwu zasad i ewentualne sformułowanie wniosków de lege ferenda.

Wymóg posiadania nieskazitelnego charakteru jest sui generis metapowinnością, wstępną i zarazem zasadniczą przesłanką z woli ustawodawcy przesądzającą o dysponowaniu kompetencjami moralnymi niezbędnymi do objęcia stanowisk, o których była mowa wyżej. Prima facie z językowego punktu widzenia znaczenie pojęcia wydaje się jednoznaczne. Nieskazitelny charakter to taki, który jest niczym nieskażony, nieskazitelność zaś to stan jednoznacznie uniemożliwiający sformułowanie jakiegokolwiek zarzutu natury moralnej w stosunku do profesjonalisty. Zapytać można, jaka jest faktyczna treść pojęcia, jakie wartości je wypełniają, innymi słowy - podjąć próbę opisania, czym jest nieskazitelność, nie zaś - jak w przypadku zaprezentowanego ujęcia negatywnego - czym nie jest. Tak oto przechodzimy do obecnych w literaturze i orzecznictwie prób skonstruowania ideału przez przypisanie mu w jednoznaczny sposób cech konstytuujących nieskazitelność. To paradoks, bo choć te próby nigdy nie dadzą w pełni zadowalającego rezultatu, to prowadzone $\mathrm{w}$ ich ramach poszukiwania mają głęboki sens. W literaturze podkreśla się, że np. sędzia powinien wykazywać się takimi cechami, jak:

[...] uczciwość, pracowitość, zrównoważenie, sumienność, odwaga, cierpliwość, wysoka kultura osobista, bystrość, uprzejmość, samokrytycyzm, otwartość intelektualna, wewnętrzne poczucie niezależności, umiejętność jasnego wyrażania swoich myśli oraz dyskursywnego rozumowania. Wymagać należy od niego także by był: wrażliwy, miał poczucie sprawiedliwości i słuszności z jednoczesną skłonnością do rozumnego kompromisu; wykazywał się surowością i rygoryzmem w stosowaniu przepisów procesowych ${ }^{6}$.

4 Zmiana została dokonana przez art. 1 pkt 7 ustawy z dnia 24 maja 2007 r. o zmianie ustawy o komornikach sądowych i egzekucji oraz niektórych innych ustaw (Dz.U. z 2007 r., nr 112, poz. 769).

5 To zestawienie zupełnie przykładowe. Zob. art. 25 ust. 1 ustawy z dnia 6 kwietnia 1990 r. o Policji (t.j. Dz.U. z 2011 r., nr 287, poz. 1687 z późn. zm.); art. 4 pkt 5 ustawy z dnia 21 listopada 2008 r. o służbie cywilnej (t.j. Dz.U. z 2014 r., poz. 111 z późn. zm.); art. 6 ust. 3 pkt 3 ustawy z dnia 21 listopada 2008 r. o pracownikach samorządowych (t.j. Dz.U. z 2014 r., poz. 1202); art. 2 pkt 2 ustawy z dnia 18 grudnia 1998 r. o pracownikach sądów i prokuratury (t.j. Dz.U. z 2015 r., poz. 1241).

6 S. Dąbrowski, A. Łazarska, Dziat II. Sędziowie, [w:] Prawo o ustroju sądów powszechnych. Komentarz LEX, red. A. Górski, Warszawa 2013, s. 281. Obszernie na temat wykazu cech i wymo- 
Chyba nietrudno zauważyć, że niektóre cechy charakteru i wymogi, stanowiące ich konsekwencje, pozostają ze sobą w kolizji, nadto pewne spośród nich nie tylko nie mają moralnego charakteru, ale nawet pośredniego związku z moralnością. Więcej nawet $-\mathrm{w}$ miarę rozrastania się katalogu i precyzowania przymiotów nieskazitelnego charakteru zmniejsza się nadzieja na koherencję między konstytuującymi go cechami i wymogami. Gdzie zatem ukrywa się ten sens? Po pierwsze, w prowadzeniu poszukiwań, co samo w sobie skłania do refleksji nad pożądanym obrazem moralnym profesjonalisty (sędziego, prokuratora, notariusza). Po wtóre, w nieuchronności wniosku, że konieczna jest zmiana optyki, porzucenie prób konstruowania odpowiedzi na pytanie, jaki jest nieskazitelny sędzia (notariusz, prokurator) i zastąpienia ich pytaniem, jaki powinien być profesjonalista, by zbliżyć się do nieosiągalnego ideału.

Wymóg nieskazitelności należy ocenić jako fikcję, stan niemożliwy do zrealizowania. Przemawia za tym doświadczenie życiowe - wszak nie ma ludzi idealnych. Potwierdzenie tej dość oczywistej tezy odnajdziemy zarówno w aktach ustrojowo-pragmatycznych, jak i w orzecznictwie. Gdyby ustawodawca wymóg ów traktował serio, to operowałby zero-jedynkową skalą odpowiedzialności. Występowałaby tylko jedna kara - złożenie z urzędu (inna równoważna). Tak jednak nie jest. Podobnie sądy dyscyplinarne, orzekając każdą ,niekapitacyjną” karę dyscyplinarną, ustalają przecież istnienie skazy na charakterze profesjonalisty. W tym stanie rzeczy niewątpliwie słusznie Sąd Najwyższy - Sąd Dyscyplinarny w szeregu swoich orzeczeń zwrot „nieskazitelność” bierze w cudzysłów?

\section{Faktyczna treść klauzuli. Względna nieskazitelność charakteru i jej standardy}

Jaka jest faktyczna treść pojęcia? Czym jest względna nieskazitelność charakteru? Miarodajna będzie tutaj pozycja nieskazitelności wśród innych powinności deontologicznych. Z reguły posiadają one charakter klauzul - to specyfika analizowanego obszaru regulacji. Nieskazitelność charakteru jest jedną z nielicznych podstawowych powinności umieszczonych poza rotą ślubowań profesjonalistów;

\footnotetext{
gów łączonych z nieskazitelnym charakterem pisze J. Bodio, „Nieskazitelność charakteru” jako kwalifikacja zawodowa sędziego (wpływajaca na jego wizerunek), „Kwartalnik Krajowej Szkoły Sądownictwa i Prokuratury" 2013, nr 4, s. 7 i n.

7 Tak: uchwała SN z dnia 7 lipca 2009 r., SNO 17/09, www.sn.pl/orzecznictwo/SitePages/ Baza_orzeczen.aspx?Sygnatura=sno\%2017/09 [dostęp: 10.06.2016]; uchwała SN z dnia 17 kwietnia 2007 r., SNO 20/07, www.sn.pl/orzecznictwo/SitePages/Baza_orzeczen.aspx ?Sygnatura $=$ sno $\% 20$ 20/07 [dostęp: 10.06.2016]; postanowienie SN z dnia 12 czerwca 2003 r., SNO 29/03, www.sn.pl/ orzecznictwo/SitePages/Baza_orzeczen.aspx?Sygnatura=sno\%2029/03 [dostęp: 10.06.2016]; wyrok SN z dnia 9 czerwca 2005 r., SNO 28/05, www.sn.pl/orzecznictwo/SitePages/Baza_orzeczen. aspx?Sygnatura $=$ sno $\% 2028 / 05$ [dostęp: 10.06 .2016 ].
} 
obok niej znajdują się między innymi obowiązek stałego podnoszenia kwalifikacji zawodowych oraz obowiązek stania na straży powagi stanowiska ${ }^{8}$. W rotach ślubowań analizowanej grupy prawników odnajdziemy natomiast między innymi obowiązki wspólne dla sędziów i prokuratorów, tj. wierność Rzeczypospolitej, stanie na straży prawa, sumienność w wypełnianiu obowiązków, dochowanie tajemnicy prawnie chronionej, kierowanie się zasadami godności i uczciwości ${ }^{9}$. Niezależnie od nich występują już na poziomie nominalnym różnice w zakresie podstawowych wymogów deontologicznych. Sędziowie np. są zobligowani do bezstronności w wymierzaniu sprawiedliwości, kierowania się własnym sumieniem w jej wymierzaniu oraz orzekania zgodnie z przepisami prawa; prokuratorzy natomiast mają stać na straży prawa i praworządności oraz kierować się zasadą bezstronności i równego traktowania obywateli ${ }^{10}$. U notariuszy wreszcie znajdziemy nieco osobliwą powinność, występującą także u komorników, tj. obowiązek kierowania się zasadami godności, honoru i uczciwości ${ }^{11}$.

Szczególne umiejscowienie tytułowej klauzuli, co prawda poza centrum deontologicznym określonym przez roty ślubowań, ale zarazem niejako na wstępie regulacji ustrojowo-pragmatycznych, wskazuje na podstawowy jej charakter, co znajduje potwierdzenie w szczegółowym układzie relacji (stosunek treściowy, pojęciowy) z pozostałymi powinnościami. W moim odczuciu elementarne znaczenie ma stosunek pomiędzy nieskazitelnością a dbałością o zachowanie godności urzędu, o której mowa w przepisach wskazujących podstawy odpowiedzialności dyscyplinarnej ${ }^{12}$. Istotę wzajemnej relacji może oddać twierdzenie, że utrata przymiotu nieskazitelności oznacza, że dany podmiot nie jest już godny pełnionego urzędu (zajmowanego stanowiska).

8 Wymóg nieskazitelności charakteru określają: art. 61 ust. 2 § 1 ustawy prawo o u.s.p., art. 14 ust. 1 pkt 2 ustawy o prokuraturze, art. 11 pkt 2 ustawy - Prawo o notariacie. Wymóg stania na straży powagi stanowiska wynika $\mathrm{z}$ art. $82 \S 2$ ustawy prawo u.s.p., art. 44 ustawy o prokuraturze, art. 19 ustawy - Prawo o notariacie. Wymóg stałego podnoszenia kwalifikacji zawodowych wynika $\mathrm{z}$ art. $82 \S 1$ ustawy prawo o u.s.p., art. 44 ustawy o prokuraturze, art. 17 ustawy - Prawo o notariacie.

9 Art. 66 ustawy prawo o u.s.p., art. 45 ustawy o prokuraturze.

10 Art. 66 ustawy prawo o u.s.p., art. 45 i 7 ustawy o prokuraturze.

11 Art. $15 \S 1$ ustawy - Prawo o notariacie oraz art. 14 ust. 2 u.k.s.e.

12 Zgodnie z art. 107 § 1 ustawy prawo o u.s.p.: „Za przewinienia służbowe, w tym za oczywistą i rażącą obrazę przepisów prawa i uchybienia godności urzędu (przewinienie dyscyplinarne), sędzia odpowiada dyscyplinarnie”. Zgodnie z art. 66 ust. 1 ustawy o prokuraturze: „Prokurator odpowiada dyscyplinarnie za przewinienia służbowe, w tym za oczywistą i rażącą obrazę przepisów prawa i uchybienia godności urzędu prokuratorskiego". Art. 50 ustawy - Prawo o notariacie przewiduje, że: „Notariusz odpowiada dyscyplinarnie za przewinienia zawodowe, w tym za oczywistą i rażącą obrazę przepisów prawnych, uchybienia powadze lub godności zawodu, jak również za niespełnienie obowiązku zawarcia umowy ubezpieczenia, o którym mowa w art. 19a, zgodnie z przepisami wydanymi na podstawie art. 19b, oraz za niewykonanie obowiązku, o którym mowa w art. $71 \S 8$, i niewykonanie zobowiązania, o którym mowa w art. 71a $\S 5$ ”. 
Nieskazitelność nie jest typową powinnością, jest „cechą charakteru”. W tym stanie rzeczy, niezależnie od wątpliwości związanych z nomenklaturą, bezpośrednim przedmiotem oceny nie jest charakter (element materialny), ale to, co stanowi jego emanację, ujawnia się na zewnątrz (element formalny) ${ }^{13}$. W kontekście powyższych uwag uzasadnione będzie moim zdaniem dokonanie rozróżnienia nieskazitelności materialnej (wewnętrznej, właściwej) i nieskazitelności formalnej (zewnętrznej) oraz uznanie, że ocenie podlega tylko ten zewnętrzny aspekt nieskazitelności. Określają go konkretne zachowania dowodzące nieskazitelności bądź nie; zachowania te są de facto potwierdzeniem bądź zaprzeczeniem dochowania wierności jakiejś konkretnej powinności. Analiza aktualnie obowiązujących regulacji oraz orzecznictwa Sądu Najwyższego - Sądu Dyscyplinarnego nie pozostawia wątpliwości: mamy dwa domniemania - jedno, że sędzia (prokurator i notariusz oraz asesorzy i aplikanci, asystenci i referendarze) ma nieskazitelny charakter, oraz drugie, że jest godny pełnionego urzędu ${ }^{14}$.

Orzeczenie kary dyscyplinarnej wiążące się ze stwierdzeniem uchybienia godności urzędu jest tożsame z przyznaniem, że istnieje skaza na charakterze profesjonalisty. Niezłożenie z urzędu (brak innego równoważnego orzeczenia) uzasadnia wniosek, że rozmiar uchybienia jest akceptowalny i nie doszło do przekreślenia formalnie pojmowanej nieskazitelności charakteru. Oznacza to, że obydwa domniemania może obalić wyłącznie prawomocne orzeczenie dyscyplinarne orzekające o złożeniu z urzędu (inne równoważne w skutkach orzeczenie sądu).

Próbę pogodzenia ideału z rzeczywistością stanowią zwroty, którymi posługuje się Sąd Najwyższy. Ustalając istnienie skazy na charakterze obwinionych, nie znajdując jednak podstaw do usunięcia ich ze stanowiska, używa on zwrotów: „podaje w wątpliwość nieskazitelność charakteru” czy „podważa zaufanie do nieskazitelności charakteru" ${ }^{15}$. Nie mają one ultymatywnego charakteru; po-

13 Moim zdaniem poprawniejsze byłoby mówienie o emanacji osobowości przejawiającej się w określonych zachowaniach. Zob. także: M. Laskowski, Ustawowe pojęcie „nieskazitelność charakteru”, „Prokuratura i Prawo” 2008, nr 6, s. 4-5.

14 Na przykład w uchwale SN z dnia 15 grudnia 2011 r. (SNO 46/11, www.sn.pl/orzecznictwo/SitePages/Baza_orzeczen.aspx?Sygnatura=sno\%2046/11 [dostęp: 10.06.2016]) stwierdzono: „Rację istnienia immunitetu sędziowskiego stanowi domniemanie uczciwości sędziego jako osoby o nieskazitelnym charakterze, spełniającej najwyższe standardy moralne". Teza ta stanowi dosłowne powtórzenie wcześniejszego stanowiska SN, wyrażonego między innymi w orzeczeniach z dnia 12 czerwca 2003 r., SNO 29/03, www.sn.pl/orzecznictwo/SitePages/Baza_orzeczen.aspx?Sygnatura=sno\%2029/03 [dostęp: 11.06.2016] i z dnia 17 kwietnia 2007 r., SNO 20/07, www.sn.pl/orzecznictwo/SitePages/Baza_orzeczen.aspx?Sygnatura=sno\%2020/07 [dostęp: 11.06.2016].

15 Tak w orzeczeniach SN: z dnia 20 września 2007 r., SNO 60/07, www.sn.pl/orzecznictwo/SitePages/Baza_orzeczen.aspx?Sygnatura=sno\%2060/07 [dostęp: 12.06.2016], z dnia 20 czerwca 2013 r., SNO 8/13, www.sn.pl/orzecznictwo/SitePages/Baza_orzeczen.aspx?Sygnatura=sno\%208/13 [dostęp: 12.06.2016], z dnia 27 czerwca 2008 r., SNO 51/08, www.sn.pl/orzecznictwo/SitePages/Baza_orzeczen. aspx?Sygnatura=sno\%2051/08 [dostęp: 12.06.2016], z dnia 12 marca 2009 r., SNO 9/09, www.sn.pl/ orzecznictwo/SitePages/Baza_orzeczen.aspx?Sygnatura=sno\%209/09 [dostęp: 12.06.2016]. 
służenie się nimi jest równoznaczne z uznaniem, iż mimo wszystko nie doszło do przekreślenia formalnie pojmowanej, względnej nieskazitelności charakteru. W ten sposób kreowane są standardy nieskazitelności będące faktycznie próbą określenia stopnia naganności poszczególnych typów zachowania, a następnie ich kwalifikowania jako mniej lub bardziej znaczącego podważenia bądź przekreślenia formalnie pojmowanej nieskazitelności charakteru.

Ograniczając się w tym miejscu tylko i wyłącznie do orzecznictwa Sądu Najwyższego - Sądu Dyscyplinarnego, można wskazać kilka takich dość wyraźnie zarysowujących się standardów. Kreowane są one nie tylko w drodze powtarzalności ocen, ale także uogólniającej formy ustaleń tego sądu i wiążą się z uznaniem obciążającego charakteru nagminności nagannych zachowań, zarówno w służbie, jak i poza nią ${ }^{16}$, oraz przyjęciem, że co do zasady prawomocne skazanie za przestępstwo jest równoznaczne z utratą przymiotu nieskazitelności charakteru ${ }^{17}$. Sztywność drugiego z przywołanych założeń przełamuje także przyjmująca charakter standardu teza o konieczności łagodniejszej oceny zachowań profesjonalistów, którzy dopuścili się tzw. przestępstw cywilizacyjnych ${ }^{18}$.

16 Sąd Najwyższy - Sąd Dyscyplinarny podniósł, że: „Sędzia nagminnie dopuszczający się rażących naruszeń obowiązków służbowych, których należyte wykonywanie ma zasadnicze znaczenie dla zachowania dobra i powagi wymiaru sprawiedliwości, traci przymiot »nieskazitelności« charakteru i musi liczyć się - biorąc w szczególności pod uwagę stopień zawinienia oraz społecznej szkodliwości dokonanych czynów - z najsurowszą karą złożenia z urzędu". Wyrok SN z dnia 9 czerwca 2005 r., SNO 28/05, www.sn.pl/orzecznictwo/SitePages/Baza_orzeczen.aspx?Sygnatura$=$ sno $\% 2028 / 05$ [dostęp: 10.06.2016].

17 W wyroku z dnia 21 października 2008 r. (SNO 78/08, www.sn.pl/orzecznictwo/SitePages/ Baza_orzeczen.aspx?Sygnatura=sno\%2078/08 [dostęp: 10.06.2016]), Sąd Najwyższy - Sąd Dyscyplinarny stwierdził: ,[...] za przewinienie dyscyplinarne, którego opis odpowiada ustawowym znamionom czynu zabronionego stypizowanego jako przestępstwo umyślne, karą odpowiednią powinno być, z reguły, złożenie sędziego z urzędu. Tego rodzaju przewinienie nie tylko dyskwalifikuje sędziego, od którego wymaga się nieskazitelnego charakteru [podkr. - G. Ł.], ale także podważa zaufanie obywateli do wymiaru sprawiedliwości. W konsekwencji, nie powinien wymierzać sprawiedliwości sędzia, który sam dopuszcza się czynu, którego opis odpowiada znamionom przestępstwa umyślnego". Analogiczne tezy odnajdziemy w innych orzeczeniach tego sądu. Zob. także: wyrok SN z dnia 26 maja 2014 r., SNO 20/14, www.sn.pl/orzecznictwo/ SitePages/Baza_orzeczen.aspx?Sygnatura=sno\%2020/14 [dostęp: 10.06.2016].

18 W uchwale SN z dnia 15 września 2004 r. (SNO 34/04, www.sn.pl/orzecznictwo/SitePages/ Baza_orzeczen.aspx?Sygnatura=sno\%2034/04 [dostęp: 14.06.2016]), stwierdzono: „Postępowanie karne przeciw sędziemu stanowi jego stygmatyzację i utrudnia funkcjonowanie w strukturze wymiaru sprawiedliwości, choć jest oczywiste, że w wielu wypadkach popełnienie $\mathrm{z}$ winy nieumyślnej występku o charakterze tzw. cywilizacyjnym nie dyskwalifikuje sędziego w świetle wymagania nieskazitelności charakteru (art. $61 \S 1$ pkt 2 u.s.p.). Ponieważ stanowi zarazem przewinienie służbowe, w razie bardzo niskiego stopnia szkodliwości społecznej czynu Sąd Dyscyplinarny może rozważać, czy kara dyscyplinarna o dolegliwości porównywalnej ze środkami stosowanymi w podobnych wypadkach w postępowaniu karnym (np. w razie warunkowego umorzenia postępowania) nie czyni zadość zasadzie sprawiedliwej odpłaty i prewencji ogólnej”. Zob. także ocenę przestępstw cywilizacyjnych w uchwałach SN: z dnia 12 czerwca 2003 r., SNO 29/03, www.sn.pl/orzecznictwo/ 
Niewątpliwie zauważalny jest brak jednolitych standardów dla analizowanej grupy profesjonalistów. Odrębności można dostrzec w dwóch zasadniczych obszarach, tj. zarówno analizując treści wiązane z nieskazitelnością $\mathrm{w}$ ramach różnych struktur (zawodów, służb, profesji), jak i - co znacznie mniej zrozumiałe - w ramach każdej spośród nich. Dodatkowym kryterium dyferencjacji ocen we wskazanych obszarach jest moment temporalny (upływ czasu).

Nieskazitelnym charakterem należy się wykazywać, aby zostać sędzią, prokuratorem i notariuszem. Utrata któregokolwiek z tych stanowisk z powodu formalnie pojmowanej utraty nieskazitelnego charakteru stanowi konsekwencję prawomocnego orzeczenia sądu dyscyplinarnego o złożeniu z urzędu bądź równoważnego w skutkach orzeczenia sądu karnego. Tymczasem mandat ławnika, od którego także wymaga się nieskazitelności charakteru, wygasa z mocy samego prawa wobec skazania go za przestępstwo (przestępstwo skarbowe) oraz wykroczenie $^{19}$. Skazanie takie ławnika nie zawsze będzie dowodem braku nieskazitelnego charakteru. Nawet jeśli traktujemy pojęcie nieskazitelności restrykcyjnie, to i tak wyjątkowo można wyobrazić sobie usuwanie sędziów ze stanowisk za wykroczenia ${ }^{20}$. Nie następuje też ono z mocy samego prawa. Jakie stąd można wyprowadzić wnioski? Po pierwsze, od ławników ustawodawca wymaga więcej pod względem moralnym niż od sędziów. Wniosek absurdalny, choć przecież uzasadniony. Po drugie, ławników i tej instytucji nie traktuje się poważnie.

Kolejne zagadnienie wiąże się z przebiegiem kariery prawniczej. Od kandydatów do godności (urzędu) sędziego, prokuratora i notariusza wymaga się nieskazitelności charakteru. Owszem, wymóg jest rozumiany formalnie, ale jednak sprawdza się odpowiednie informacje i dane ${ }^{21}$. Negatywny wynik badania stanowi skuteczną zaporę w zabiegach o powołanie na stanowisko. Racjonalne

SitePages/Baza_orzeczen.aspx?Sygnatura=sno\%2029/03 [dostęp: 14.06.2016], z dnia 28 września 2004 r., SNO 35/04, www.sn.pl/orzecznictwo/SitePages/Baza_orzeczen.aspx?Sygnatura $=$ sno $\% 20$ 35/04 [dostęp: 14.06.2016], z dnia 5 lipca 2006 r., SNO 32/06, www.sn.pl/orzecznictwo/SitePages/ Baza_orzeczen.aspx?Sygnatura=sno\%2032/06 [dostęp: 14.06.2016].

19 Art. $166 \S 1$ prawa o u.s.p. stanowi: „Mandat ławnika wygasa w razie prawomocnego skazania za przestępstwo bądź wykroczenie, w tym również za przestępstwo lub wykroczenie skarbowe. Rada gminy, która wybrała ławnika, stwierdza wygaśnięcie mandatu z tego powodu i informuje o tym prezesa właściwego sądu".

20 W wyroku z dnia 26 kwietnia 2010 r. Sąd Najwyższy podkreślił, że: „Za wykroczenie sędzia odpowiada dyscyplinarnie (art. 81 u.s.p.), jeżeli stanowi ono przewinienie dyscyplinarne w rozumieniu art. $107 \S 1$ u.s.p.”.

21 Odpowiednie regulacje zawierają ustawy ustrojowo-pragmatyczne, np. art. 58 prawa o u.s.p. Na podstawie upoważnienia zawartego w $§ 7$ tego artykułu zostało wydane rozporządzenie Ministra Sprawiedliwości z dnia 21 marca 2012 r. w sprawie sporządzania informacji o kandydacie do objęcia stanowiska sędziowskiego (Dz.U. z 2012 r., poz. 332). Zgodnie z § 3 ust. 1 rozporządzenia: „Komendant Policji zarządza zebranie informacji przetwarzanych na temat kandydata $\mathrm{w}$ policyjnych systemach teleinformatycznych stanowiących podstawę sporządzenia informacji o kandydacie". 
z psychologicznego punktu widzenia, choć niebezpieczne z perspektywy realizacji tytułowej zasady, staje się w szczególności założenie, że w stosunku do osoby, która - po pokonaniu kolejnych szczebli kariery - zostaje w końcu członkiem „korporacji”, pojawia się swoisty „solidaryzm” i wola traktowania jej jako „swojej". W tym momencie zaczyna też obowiązywać domniemanie nieskazitelności charakteru, którego obalenie następuje przecież tylko wtedy, gdy orzeczono karę najsurowszą (wydano orzeczenie w postępowaniu karnym skutkujące równoważnymi konsekwencjami). Istotę problemu doskonale oddaje argumentacja Sądu Najwyższego odmawiającego uchylenia immunitetu sędziemu oskarżonemu o przestępstwo cywilizacyjne ${ }^{22}$. Trudno także wyobrazić sobie powołanie na stanowisko sędziego kandydata skazanego za przestępstwo stypizowane w art. 178a $\S 1$ k.k. Zapewne, nawet mimo zatarcia skazania, takie zachowanie stanowiłoby w oczach KRS podstawę uznania, że nie dysponuje on nieskazitelnym charakterem. Tymczasem sędzia w stanie spoczynku, który dopuścił się wspomnianego czynu, skazany został najpierw na karę dyscyplinarną nagany (I instancja), później zaś na karę wstrzymania waloryzacji uposażenia na okres dwóch lat ${ }^{23}$.

${ }^{22}$ W uchwale SN z dnia 5 lipca 2006 r., SNO 32/06, podkreślono: „Doceniając publicznoprawne znaczenie immunitetu oraz jego funkcję ochronną, należy podkreślić, że zezwolenie na pociągnięcie sędziego (asesora sądowego) do odpowiedzialności karnej sądowej lub administracyjnej powinno być udzielane z rozwagą, po zbadaniu wszystkich okoliczności i po dokonaniu wnikliwej oceny, czy przedstawione przez uprawniony organ materiały uzasadniają podejrzenie popełnienia przez sędziego przestępstwa. Chodzi o podejrzenie w pełni uzasadnione, nienasuwające żadnych istotnych wątpliwości lub zastrzeżeń, zarówno co do popełnienia samego czynu, jak i występowania innych znamion objętych przez ustawę ramami zasad odpowiedzialności karnej. Dotyczy to w szczególności przestępstw tzw. cywilizacyjnych, w tym zwłaszcza występków przeciwko bezpieczeństwu w komunikacji, popełnianych czynem nieumyślnym, mieszczącym się w ryzyku związanym nieodłącznie z uczestnictwem w ruchu lądowym. Przypadki te wymagają dużej ostrożności i wnikliwości co do oceny winy sprawcy czynu. Przy ocenie czynów kwalifikowanych jako nieumyślne naruszenie zasad bezpieczeństwa w ruchu lądowym nietrudno o formułowanie podejrzeń przedwczesnych lub pochopnych, które w odniesieniu do sędziego - zważywszy na niebezpieczeństwo bezzasadnego zakwestionowania »nieskazitelności« jego charakteru - mogą spowodować nieodwracalne skutki dla jego służby sędziowskiej. Skazanie sędziego za popełnienie czynu kwalifikowanego jako nieumyślne naruszenie zasad bezpieczeństwa w ruchu lądowym, a nawet warunkowe umorzenie postępowania w stosunku do sędziego - rodzi, z oczywistych przyczyn, nieporównywalne skutki dla jego życia zawodowego i prywatnego w porównaniu ze skutkami ponoszonymi z tego samego powodu przez innych "przeciętnych obywateli«, o których sytuacji prawnej wspomina skarżący w zażaleniu w kontekście popełnienia nieumyślnego występku przeciwko bezpieczeństwu w ruchu drogowym. Także z tego względu przy składaniu i rozpatrywaniu wniosku o zezwolenie na pociągnięcie sędziego do odpowiedzialności karnej uzasadniona jest szczególna ostrożność zarówno oskarżyciela (organu prowadzącego postępowanie karne), jak i sądu".

23 Wyrok SN z dnia 15 czerwca 2011 r., SNO 25/11, www.sn.pl/orzecznictwo/SitePages/Baza orzeczen.aspx?Sygnatura=sno\%2025/11 [dostęp: 14.06.2016]. W uzasadnieniu swego orzeczenia Sąd Najwyższy podniósł między innymi: „W przypadku obwinionego czyn obwinionego kwalifikuje się do najcięższych przewinień dyscyplinarnych, zatem kara dyscyplinarna musi być odpowiednio surowa. Sam fakt, że zachowanie obwinionego nosiło znamiona występku określonego w art. 178a $§ 1$ k.k., 
Jeśli chodzi o zagadnienie czasu, to w grę wchodzi także złożony kompleks problemów związanych z oceną możności odnowienia się nieskazitelnego charakteru i ubiegania się o pierwsze oraz ponowne powołanie na stanowisko. Naganne zachowanie skutkujące uznaniem, że kandydat nie wykazuje się nieskazitelnym charakterem, może nastąpić zarówno przed objęciem stanowiska, w toku pełnienia służby (wykonywania zawodu), jak i po usunięciu z niej na skutek uznania braku przymiotu nieskazitelności charakteru ${ }^{24}$. W związku z analizowaną problematyką pozostaje także ocena skutków: zatarcia skazania, przedawnienia ścigania i przedawnienia wykonania kary.

Istota problemu sprowadza się moim zdaniem do dwóch zagadnień. Po pierwsze, kwestii dotyczących tego, że od przyszłego profesjonalisty wymaga się, by w dacie powołania dysponował ,nieskazitelnym charakterem” oraz, po drugie, przysługujących każdemu obywatelowi praw (uprawnień, dobrodziejstw) wynikających z instytucji przedawnienia i zatarcia skazania. Sędzia, prokurator czy notariusz nie są oczywiście zwykłymi obywatelami, w wielu momentach swego życia są ograniczeni pełnioną służbą; na ogół zresztą te obywatelskie deficyty po prostu akceptują. Doskonale można to wykazać, odwołując się do przykładów historycznych ${ }^{25}$; odnosząc uwagi wprost do sędziów, nieskazitelność to zasada oraz pożądany stan istniejące $\mathrm{w}$ pierwszym rzędzie w interesie obywatela, zarazem jednak także to jedne z zasadniczych gwarancji prawa do sądu, czyli realizacji normy wynikającej z art. 45 Konstytucji $\mathrm{RP}^{26}$. Każdy, stając przed sądem, ma prawo oczekiwać, że osądzi go sędzia bezstronny i niezawisły, a więc „nieskazitelnego charakteru". Nieskazitelność jest bowiem warunkiem sine qua non bezstronności i niezawisłości ${ }^{27}$.

w okolicznościach sprawy, nie uzasadnia jednak wymierzenia najwyższej kary dyscyplinarnej określonej w art. 104 u.s.p. Przepisy kodeksu karnego różnicują ciężar gatunkowy przestępstw granicami przewidzianej kary. Czyn określony w art. 178a $§ 1$ k.k., zagrożony karą do dwóch lat pozbawienia wolności, nie należy do przestępstw najpoważniejszych, a ponadto został popełniony w okolicznościach, które pozwalają na łagodniejsze potraktowanie jego sprawcy. Stąd, w ocenie Sądu Najwyższego - Sądu Dyscyplinarnego, kara zawieszenia waloryzacji uposażenia na okres dwóch lat daje wystarczający sygnał, że czyny godzące w autorytet wymiaru sprawiedliwości nie pozostają bezkarne. Jest to kara dotkliwa i wymierzenie jej czyni zadość wymogom prewencji ogólnej”.

24 Zob. także uwagi G. Borkowskiego na temat uprzedniej i następczej kontroli nieskazitelności charakteru w: Nieskazitelność charakteru a powołanie do wykonywania zawodów prawniczych, [w:] Etyka zawodów prawniczych w praktyce. Wzajemne relacje i oczekiwania, red. G. Borkowski, Lublin 2012, s. 209-210.

25 Wymowna może być tutaj dyskusja na temat zakazu przynależności sędziów do partii politycznych, która toczyła się w II Rzeczypospolitej. Szerzej na ten temat: G. Ławnikowicz, Idea niezawisłości sędziowskiej w porządku prawnym i myśli prawniczej II RP, Toruń 2009, s. 365-368.

26 Przepis ten stanowi: „Każdy ma prawo sprawiedliwego i jawnego rozpatrzenia sprawy bez nieuzasadnionej zwłoki przez właściwy, niezależny, bezstronny i niezawisły sąd".

27 To oczywiście pewna idealizacja i pewne uproszczenie. Niezawisłość (podobnie jak służąca jej nieskazitelność) ze względu na słabość ludzkiej natury także ma charakter względny. Zasadnie 
Czy istnieje możność odnowienia się nieskazitelności charakteru? Wydaje się, że jest to nierealne. Istotą charakteru jest bowiem trwałość - „słabość” czy „zmienność" to także jego trwałe cechy. Zatarcie skazania kreuje fikcję, że skazanie nie nastąpiło, nie znosi jednak czynu, który stanowił podstawę zatartego skazania. W tym stanie rzeczy istnieje co najwyżej możliwość przyjęcia swoistej fikcji, że doszło (mogło dojść) do odnowienia nieskazitelności charakteru. Taka fikcja nie została przyjęta $\mathrm{w}$ stosunku do prokuratorów, a $\mathrm{w}$ odniesieniu do sędziów została wyraźnie wykluczona ${ }^{28}$. Formalne stwierdzenie braku nieskazitelnego charakteru faktycznie zamyka drogę ubiegania się o ponowne powołanie na stanowiska sędziego i prokuratora. Wydaje się, że zawsze podstawą oceny charakteru powinien być czyn, co oznacza konieczność wyrzeczenia się wszelkiego automatyzmu i uznanie, że skazanie (szerzej - czyn stanowiący jego podstawę) należy oceniać przez pryzmat aktualnych standardów nieskazitelności. Ocena winna być „dynamiczna” - skoro funkcje miałyby być pełnione (także ponownie) już po dokonaniu oceny, to organ jej dokonujący winien czuć się związany nie tyle treścią orzeczenia, ile ustalonym stanem faktycznym i aktualnymi wyobrażeniami o treściach konstytuujących nieskazitelność ${ }^{29}$.

Inaczej ustawodawca potraktował notariuszy. Ta odrębność regulacji jest niewątpliwie konsekwencją wyroku Trybunału Konstytucyjnego z dnia 18 października 2010 r. $^{30}$ Zgodnie z art. $51 \S 4$ ustawy - Prawo o notariacie osoba, która przestała być notariuszem w związku z wymierzeniem kary dyscyplinarnej pozbawienia prawa prowadzenia kancelarii, może ponownie ubiegać się o powołanie na notariusza po upływie 10 lat od dnia uprawomocnienia się wyroku ${ }^{31}$. Niewątpli-

w międzywojennej dyskusji odróżniano od siebie niezawisłość wewnętrzną i zewnętrzną. Szerzej na ten temat: G. Ławnikowicz, op. cit., s. 384 i n.

28 Zgodnie z art. 109 § 4 prawa o u.s.p. „Wymierzenie kary określonej w $\S 1$ pkt 5 [tj. kary złożenia sędziego z urzędu - G. Ł.] pociąga za sobą utratę możliwości ponownego powołania ukaranego do pełnienia urzędu na stanowisku sędziowskim".

29 Brak w ustawie o prokuraturze odpowiednika art. $109 \S 4$ prawa o u.s.p. mógłby uzasadniać dopuszczalność ponownego badania czynu osoby ubiegającej się o powołanie na stanowisko prokuratora.

${ }^{30}$ W orzeczeniu tym Trybunał Konstytucyjny uznał między innymi, że: „1. Art. 65 ust. 2c ustawy z dnia 6 lipca 1982 r. o radcach prawnych (Dz.U. z 2010 r., nr 10, poz. 65 i nr 47, poz. 278) w zakresie, w jakim zawiera sformułowanie »bez prawa ubiegania się o ponowny wpis«, 2. Art. 82 ust. 2 ustawy z dnia 26 maja 1982 r. - Prawo o adwokaturze (Dz.U. z 2009 r., nr 146, poz. 1188, nr 166, poz. 1317, $\mathrm{nr} 210$, poz. 1628 i nr 216, poz. 1676 oraz z 2010 r., nr 7, poz. 45 i nr 47, poz. 278) w zakresie, w jakim zawiera sformułowanie »bez prawa ubiegania się o ponowny wpis«, [...] a) są zgodne z art. 32 ust. 1 Konstytucji Rzeczypospolitej Polskiej, b) są niezgodne z art. 65 ust. 1 w związku z art. 31 ust. 3 Konstytucji”. Wyrok TK z dnia 18 października 2010 r., sygn. K 1/09 (Dz.U. z 2010 r., nr 200, poz. 1326).

31 Art. $51 \S 4$ ustawy - Prawo notariacie otrzymał następujące brzmienie: „Osoba, która przestała być notariuszem w związku z orzeczeniem kary dyscyplinarnej, o której mowa w $§ 1$ pkt 4 [tj. kary pozbawienia prawa prowadzenia kancelarii - G. Ł.], może ponownie ubiegać się o powołanie 
wie trudno wyobrazić sobie orzeczenie tej kary w sytuacji innej niż stwierdzenie braku nieskazitelnego charakteru. Przepis ten statuuje zatem wyjątek - fikcję i dopuszcza sanowanie charakteru oraz powrót do formalnie pojmowanej nieskazitelności. Także tutaj nie ma jednak automatyzmu; ustawodawca nie przesądził o „odnowieniu się nieskazitelności charakteru”, a jedynie taką ewentualność wyraźnie dopuścił przez użycie zwrotu: „może ponownie ubiegać się”. Oznacza to konieczność dokonania powtórnej oceny charakteru kandydata. Wydaje się, że powinna ona obejmować zarówno zachowanie stanowiące podstawę orzeczonej kary, jak i późniejszą postawę ukaranego. Bez większego trudu można sobie wyobrazić zachowania na tyle skrajne, że same przez się ewidentnie zamykające powrót do zawodu notariusza. Jednakże postawa ukaranego już po uprawomocnieniu się orzeczenia sądu dyscyplinarnego będzie zawsze korygowała wyobrażenie o statusie moralnym kandydata; nigdy nie zniesie, ale skutecznie może ograniczyć ujemną ocenę charakteru. Omawiana regulacja ma charakter specjalny i jako taka potwierdza tezę, że sędziowie i prokuratorzy nie mogą „odzyskać” przymiotu nieskazitelności. W przeciwnym wypadku ustawodawca wprowadziłby analogiczne regulacje do prawa o u.s.p. i ustawy o prokuraturze.

Z czysto językowego punktu widzenia terminy „nieskazitelny” i „nieposzlakowany" są synonimami. Obydwu klauzul nie mamy jednak prawa utożsamiać. Niezależnie od tego, że użycie przez ustawodawcę różnych zwrotów dowodzi woli nadania im odmiennego znaczenia, dużo istotniejsze jest to, co te dwa przymiotniki określają. W pierwszym wypadku przedmiotem oceny jest charakter, w drugim zaś opinia o człowieku, w tym opinia o jego charakterze.

Ujmując sprawę literalnie, nie ma ludzi, którzy cieszyliby się powszechnie nieposzlakowaną opinią. Teza ta jest oczywista już choćby wobec leżącej u podstaw naszych ocen sprzeczności ludzkich interesów czy niskiego poziomu świadomości prawnej obywateli ${ }^{32}$. Nieposzlakowana opinia nie może być li tylko prywatną opinią jednostki bądź grupy ludzi, wtedy bowiem pojawia się niebezpieczeństwo su-

na notariusza po upływie 10 lat od dnia uprawomocnienia się orzeczenia kary pozbawienia prawa prowadzenia kancelarii”. Notariusze znaleźli się w takiej samej sytuacji jak adwokaci i radcowie prawni. W myśl art. 82 ust. 2 ustawy - Prawo o adwokaturze: „Kara wydalenia z adwokatury pociąga za sobą skreślenie $\mathrm{z}$ listy adwokatów bez prawa ubiegania się o ponowny wpis na listę adwokatów przez okres 10 lat od dnia uprawomocnienia się orzeczenia kary wydalenia z adwokatury". Zgodnie z art. 65 ust. 2c ustawy o radcach prawnych: „Kara pozbawienia prawa do wykonywania zawodu radcy prawnego pociąga za sobą skreślenie z listy radców prawnych bez prawa ubiegania się o ponowny wpis na listę radców prawnych przez okres 10 lat od dnia uprawomocnienia się orzeczenia kary pozbawienia prawa do wykonywania zawodu radcy prawnego".

32 W praktyce za naganne są uznawane czynności stanowiące realizację obowiązków komornika, jak np. fakt prowadzenia egzekucji z nieruchomości, czy też warunkujące skuteczność czynności egzekucyjnych zachowania kontratypowe w postaci naruszenia miru domowego, zmuszenia do określonego zachowania oraz naruszenia nietykalności cielesnej. Szerzej na ten temat: V. Konarska-Wrzosek, Odpowiedzialność karna komornika sądowego, „Przegląd Prawa Egzekucyjnego” 2006, nr 12, s. 71-73. 
biektywizowania ocen i relatywizowania elementów określających ideał osobowy (np. komornika). Stąd naturalne dążenie do odnalezienia obiektywnych, pewnych i klarownych kryteriów oceny opinii o profesjonaliście. W poszukiwaniu takiego obiektywnego punktu oparcia skłaniamy się ku jedynemu możliwemu rozwiązaniu - bierzemy pod uwagę to, co uchwytne zewnętrznie. Ocena znowu, tak jak w przypadku „nieskazitelnego charakteru”, przybiera wymiar formalny, dotyczący tego, czy dana osoba zasłużyła na nieposzlakowaną opinię, a także jakości jej zachowań. Przyjmując zatem inną perspektywę i realizując inny cel, bezpośrednim przedmiotem oceny czynimy to samo, co w przypadku ustalania nieskazitelności charakteru.

Ramy tej formalnej perspektywy określa stosunek profesjonalisty (tutaj komornika) do norm deontologii zawodowej, a zatem także do porządku prawnego ${ }^{33}$.

Nieposzlakowana opinia zostaje podważona bądź przekreślona w przypadku popełnienia większości przestępstw, czynów nagannych moralnie, czegoś, co można by określić jako złe prowadzenie się, związane choćby $\mathrm{z}$ otaczaniem się niewłaściwymi ludźmi, naganną, niegodną postawą, tak w służbie, jak i poza nią; krótko - zachowaniem sprzecznym z obowiązkiem zachowania nieuchybiającego godności urzędu ${ }^{34}$. W tym wypadku aktualność zachowują wcześniejsze uwagi o centrum deontologicznym oraz szczególnej relacji między klauzulą (tutaj nieposzlakowana opinia) a godnością urzędu komornika. Jako oczywiste wyłania się także zagadnienie standardów nieposzlakowanej opinii, które pozostaje w związku ze stopniowalnością kar orzekanych w postępowaniu dyscyplinarnym. Następstwem niestopniowalności analizowanego pojęcia (przymiotu) jest domniemanie nieposzlakowanej opinii, które może obalić tylko najsurowsza kara dyscyplinarna w postaci wydalenia ze służby komorniczej.

Wszystkie te faktyczne zbieżności mogą skłaniać do wniosku, że nieposzlakowana opinia jest „młodszą siostrą” nieskazitelnego charakteru, inną i w domyśle niższą „kwalifikacją moralną”, że użyję określenia obecnego w „ustawie lustracyjnej" ${ }^{35}$. Nie jest on w pełni uzasadniony. O ile bowiem nawet chwiejny

33 Ten stosunek precyzuje rota ślubowania komornika. Art. 14 ust. 2 u.k.s.e., który określa jej treść, otrzymał następujące brzmienie: „Ślubuję uroczyście jako komornik powierzone mi obowiązki wypełniać zgodnie z prawem i sumieniem, dochować tajemnicy prawnie chronionej, w postępowaniu swym kierować się zasadami uczciwości, godności i honoru”.

34 Zob. $§ 4$ ust. 1 Kodeksu etyki zawodowej komornika sądowego, t.j. opublikowany uchwałą KRK nr 909/IV z dnia 8 lutego 2012 r., www.komornik.pl/wp-content/uploads/2015/05/kezktj.pdf [dostęp: 15.04.2016]. Obowiązek zachowania nieuchybiającego godności urzędu można wyprowadzić $\mathrm{z}$ art. 71 u.k.s.e.

35 Tak w art. 30 ustawy z dnia 11 kwietnia 1997 r. o ujawnieniu pracy lub służby w organach bezpieczeństwa państwa lub współpracy z nimi w latach 1944-1990 osób pełniących funkcje publiczne (t.j. Dz.U. z 1999 r., nr 42, poz. 428). Przepis ten stanowi, że: „Prawomocne orzeczenie Sądu, stwierdzające fakt złożenia przez osobę lustrowaną niezgodnego z prawdą oświadczenia, jest równoznaczne $\mathrm{z}$ utratą kwalifikacji moralnych niezbędnych do zajmowania funkcji publicznych określanych w odpowiednich ustawach jako: nieskazitelność charakteru, nieposzlakowana opinia, 
charakter posiada znamię trwałości ${ }^{36}$, o tyle już w przypadku opinii jest inaczej. Opinie o ludziach się zmieniają - to truizm aktualny także w odniesieniu do komorników. Niemałą rolę w tej przemianie odgrywają stosowna ekspiacja oraz upływ czasu. W art. 72 ust. 1 pkt 4 u.k.s.e. stwierdza się, że „w przypadku wygaśnięcia powołania na stanowisko komornika z mocy prawa w związku z orzeczeniem kary dyscyplinarnej, o której mowa w ust. 1 pkt 4 [tj. kary wydalenia ze służby komorniczej - G. Ł.], osoba może ponownie ubiegać się o powołanie na stanowisko komornika po upływie 10 lat od dnia uprawomocnienia się orzeczenia". Regulacja jest bliźniacza do tej umieszczonej w prawie o notariacie. Fikcji obecnej w tamtym akcie normatywnym odpowiada jednak realistyczne założenie o możności odnowienia się nieposzlakowanej opinii.

Ścisłe powiązanie klauzuli ze stosunkiem komornika do porządku prawnego rodzi także wymierne niebezpieczeństwa, w szczególności takie, jak możność utrwalenia się przekonania, że każde formalnie potwierdzone naruszenie prawa, ba, nawet przypuszczenie jego naruszenia, bez względu na postać (popełnienie wykroczenia, wniesienie subsydiarnego aktu oskarżenia przeciwko komornikowi) podważa wymóg nieposzlakowanej opinii ${ }^{37}$.

Analizowany wymóg ma również swój wymiar wizerunkowy. W pełni zasadne wydaje się pytanie, dlaczego od komornika - funkcjonariusza publicznego wykonującego zawód zaufania publicznego - nie wymaga się (przynajmniej nominalnie) tego samego, co od osób wykonujących pięć pozostałych zawodów zaufania publicznego. Na tak postawione pytanie trudno moim zdaniem znaleźć racjonalną odpowiedź, zwłaszcza że pobieżne zestawienie tytułowych klauzul i ich adresatów może sugerować, iż komornik winien skutecznie wywoływać wrażenie uczciwości, a wszyscy pozostali profesjonaliści muszą uczciwością się wykazywać. W tym układzie, wobec wielu podobieństw statusu komornika i notariusza, choćby tożsamości składanych ślubowań, nie ma przeszkód, by na komorników rozciągnąć wymóg względnej i odnawialnej nieskazitelności charakteru w ujęciu prawa o notariacie ${ }^{38}$.

nienaganna opinia, dobra opinia obywatelska bądź przestrzeganie podstawowych zasad moralnych. Po upływie 10 lat od dnia uprawomocnienia, orzeczenie Sądu uznaje się za niebyłe".

36 Jest zatem trwale chwiejny, ponieważ chwiejność, zmienność, niestałość, słabość są in concreto, podobnie jak przeciwstawne im „twardość” czy „siła”, są elementami trwale konstytuującymi istotę charakteru.

37 To zagrożenie doskonale obrazuje orzeczenie WSA w Warszawie z dnia 21 grudnia $2009 \mathrm{r}$. (VI SA/Wa 1719/09, http://orzeczenia.nsa.gov.pl [dostęp: 14.05.2016]). Zdaniem tego sądu: ,[...] ratio legis unormowania wiążącego obligatoryjny skutek w postaci zawieszenia komornika w czynnościach $\mathrm{z}$ prowadzeniem $\mathrm{w}$ stosunku do niego postępowania karnego o umyślne przestępstwo ścigane $\mathrm{z}$ oskarżenia publicznego lub umyślne przestępstwo skarbowe - w tym także na skutek wniesienia subsydiarnego aktu oskarżenia - można wyinterpretować z treści art. 10 ust. 1 pkt 3 u.k.s.e., zgodnie z którym komornikiem może być wyłącznie osoba o nieposzlakowanej opinii”.

${ }_{38}$ Za takim rozwiązaniem przemawia także samo zestawienie art. 72 u.k.s.e. i art. 51 prawa o notariacie. 


\section{ADWOKACI I RADCY PRAWNI}

Zawód adwokata i zawód radcy prawnego to profesje związane z pomocą prawną i świadczeniem usług prawnych. Zarówno adwokat, jak i radca prawny posiadają szczególny status prawny, ich zawód jest uregulowany ustawowo, a tytuł zawodowy ,adwokat” i „radca prawny” zgodnie z ustawą - Prawo o adwokaturze i ustawą o radcach prawnych podlega ochronie prawnej39. Obie ustawy podobnie regulują zakres pomocy prawnej. Zgodnie z art. 4 ust. 1 ustawy - Prawo o adwokaturze zawód adwokata polega na świadczeniu pomocy prawnej, a w szczególności na udzielaniu porad prawnych, sporządzaniu opinii prawnych, opracowywaniu projektów aktów prawnych oraz występowaniu przed sądami i urzędami. Art. 6 ust. 1 ustawy o radcach prawnych stanowi natomiast, że świadczenie pomocy prawnej przez radcę prawnego polega w szczególności na udzielaniu porad i konsultacji prawnych, sporządzaniu opinii prawnych, opracowywaniu projektów aktów prawnych oraz występowaniu przed urzędami i sądami w charakterze pełnomocnika lub obrońcy ${ }^{40}$. Zarówno adwokat, jak i radca prawny wykonują zawód rozumiany jako zawód zaufania publicznego ${ }^{41}$, wykonywany $\mathrm{w}$ interesie publicznym i cechujący się profesjonalizmem, ważnym znaczeniem społecznym, niezależnością i nieskazitelnością charakteru, co oznacza, że adwokat i radca prawny, wykonując czynności zawodowe, kierują się specyficznymi, podwyższonymi regułami deontologicznymi, a w życiu prywatnym zachowują godność zawodu, przestrzegając zasad etycznych. Do innych ważnych cech powyższych zawodów zaliczyć można konieczność posiadania wysokich kwalifikacji i kompetencji zawodowych, samodzielność i wykonywanie czynności zawodowych osobiście, istnienie szczególnej więzi osobistej między adwokatem i radcą prawnym a klientem, opartej na wzajemnym zaufaniu, lojalności i obowiązku zachowania tajemnicy zawodowej, ponoszenie odpowiedzialności cywilnoprawnej i dyscyplinarnej za nienależyte wykonywanie zawodu adwokata czy radcy prawnego, obowiązkowy udział w samorządzie zawodowym i obowiązkowe poddanie się przepisom wewnętrznie obowiązującym wytworzonym przez samorząd adwokatów i radców prawnych. Zawody adwokata i radcy prawnego powszechnie są uznawane za profesje o szczególnym dla społeczeństwa znaczeniu jako służba publiczna sui generis, wyrażająca się w misji ochrony, rozwijania bądź gwarantowania dóbr

39 Art. 1 ust. 4 ustawy z dnia 26 maja 1982 r. - Prawo o adwokaturze (t.j. Dz.U. z 2015 r., poz. 615); art. 1 ust. 2 ustawy z dnia 6 lipca 1982 r. o radcach prawnych (t.j. Dz.U. z 2014 r., poz. 637, 993, 1778).

40 Zob. szerzej: Z. Klatka, Wykonywanie zawodu radcy prawnego i adwokata, Warszawa 2004; Zawód radcy prawnego. Historia i zasady jego wykonywania, red. A. Bereza, Warszawa 2014.

${ }_{41}$ Zob. szerzej: L. Grzonka, J. Kostrubiec, Zawód zaufania publicznego. Przyczynek do dyskusji, „Studia Iuridica Lublinensia” 2007, nr 9, s. 25 i n. 
wyższego rzędu: życia, zdrowia, własności intelektualnej, sztuki, mienia, ładu społecznego i publicznego, a także praw i wolności jednostki.

Mimo że adwokaci i radcowie prawni podlegają różnym rygorom odpowiedzialności za postępowanie sprzeczne z prawem, zasadami etyki bądź uchybienie godności zawodowej oraz mogą wykonywać zawód w różnych formach, to jednak wspólne dla obu zawodów są normy związane z rozumieniem nieskazitelnego charakteru ${ }^{42}$. Właśnie przez wymóg nieskazitelności charakteru ustawodawca próbuje zapewnić odpowiedni poziom moralny kandydatów na adwokatów i radców prawnych oraz samych adwokatów i radców prawnych.

Podkreślić można, że w literaturze przedmiotu wskazuje się, że adwokat czy radca prawny powinien mieć nie tylko nieskazitelny charakter, ale też powołanie do wykonywania danego zawodu prawniczego. Powołanie należy przy tym rozumieć jako skłonność, zdolność, zamiłowanie do czegoś, czyjeś przeświadczenie o tym, że pewien zawód, droga życiowa są dla tej osoby najwłaściwsze ${ }^{43}$. Przedstawia się również zawód radcy prawnego, ukazując cechy, które kształtują charakter czy tożsamość zawodową radcy prawnego i odpowiednio adwokata ${ }^{44}$.

Nieskazitelność charakteru na gruncie działania samorządu adwokatów i radców prawnych należy traktować jako klauzulę generalną rozumianą jako zwrot językowy będący częścią przepisu prawnego, celowo nieostry lub niedookreślony, o charakterze oceniającym, a więc wymagający od podmiotu stosującego prawo określonych wartościowań, odsyłający jednocześnie do kryteriów pozaprawnych (np. norm moralnych mających stanowić podstawę tych wartościowań), stwarzający luz decyzyjny dla organu stosującego prawo, luz wprowadzony w sposób celowy i zamierzony przez prawodawcę ${ }^{45}$. Ustawodawca, nie definiując ani w ustawie - Prawo o adwokaturze, ani w ustawie o radcach prawnych pojęcia ,nieskazitelny charakter", pozostawił zatem organom samorządu prawo decydowania o wypełnieniu treścią tego pojęcia. Zgodnie z art. 65 ust. 1 pkt 1 ustawy - Prawo o adwokaturze na listę adwokatów może być wpisany ten, kto jest nieskazitelnego charakteru i swym dotychczasowym zachowaniem daje rękojmię prawidłowego wykonywania zawodu adwokata. Z kolei zgodnie z art. 24 ust. 1 pkt 5 ustawy o radcach prawnych na listę radców prawnych może być wpisany ten, kto jest nieskazitelnego charakteru i swym dotychczasowym zachowaniem daje rękojmię prawidłowego wykonywania zawodu radcy prawnego. W przesłankach warunku-

42 R.K. Tabaszewski, Etyka i odpowiedzialność zawodowa adwokatów i radców prawnych jako przedsiębiorców, [w:] Człowiek - społeczeństwo - gospodarka. Perspektywa odpowiedzialności społecznej, red. A. Zadroga, K. Sawicki, Lublin 2013, s. 221.

43 G. Borkowski, op. cit., s. 206-207.

44 P. Kaczmarek, Rzady prawa a sprawcze wykonywanie zawodu radcy prawnego, „Radca Prawny" 2015, nr 1 (2), 180-181.

${ }_{45}$ W. Gromski, Klauzule generalne, [w:] Wprowadzenie do nauk prawnych. Leksykon tematyczny, red. A. Bator, Warszawa 2010, s. 209. 
jących możliwość wykonywania zawodu adwokata i radcy prawnego można odnaleźć dwa czynniki. Pierwszym jest nieskazitelność jako cecha charakteru, która dotyczy właściwości osobistych i wymogów etycznych. Drugim czynnikiem jest dotychczasowe zachowanie osoby ubiegającej się o wpisanie na listę adwokatów bądź radców prawnych. Czynnik ten obejmuje ocenę dotychczasowego zachowania się danej osoby w poszczególnych sferach życia społecznego ${ }^{46}$. Oba przepisy i wynikające $z$ nich normy są tożsame co do treści. W doktrynie zauważa się, że w przypadku zawodów prawniczych - adwokata i radcy prawnego - nieskazitelność charakteru jest dla ustawodawcy kryterium ważnym, lecz nie definiuje on ustawowo tego pojęcia, gdyż rozumienie terminu ,nieskazitelny charakter” nie powinno powodować zasadniczych trudności, co więcej - brak definicji wydaje się zamierzony ${ }^{47}$.

Konieczność posiadania cechy nieskazitelnego charakteru wynika z ustaw korporacyjnych i nie budzi w doktrynie i orzecznictwie wątpliwości. Problemem teoretycznym, ale i praktycznym, staje się natomiast sposób weryfikacji nieskazitelnego charakteru. Oczywiście wymaga to od organów prawniczych samorządów zawodowych decydujących o tym, kto może być wpisany na listę adwokatów lub radców prawnych, stosowania właściwej metodologii w podejściu do rozumienia „nieskazitelnego charakteru”. Ustawodawca nie tylko nie definiuje pojęcia „nieskazitelny charakter”, ale również unika wskazania metod czy konkretnych technik badawczych służących do analizy posiadania przez kandydata do zawodu adwokata czy radcy prawnego tej cechy. Wydaje się, że pomocna w podejmowaniu decyzji może być weberowska zasada Wertfreiheit oznaczająca „,wolność od wartościowania"48. Metodologia ta oznacza konieczność oddzielenia faktów od wartości. Analizując „nieskazitelny charakter”, należy opisywać pojęcie nieskazitelnego charakteru, ale nie powinno się oceniać go z własnej perspektywy aksjologicznej. Oznacza to, że organ decydujący o tym, czy dany kandydat spełnia przesłankę nieskazitelnego charakteru, powinien unikać własnych sądów wartościujących i korzystać właśnie z odniesienia do wartości. Należy w każdym indywidualnym przypadku odwoływać się do modelu typu idealnego nieskazitelnego

46 P. Kaczmarek, op. cit., s. 176.

47 M. Laskowski, Ustawowe pojęcie „nieskazitelność charakteru”, „Prokuratura i Prawo” 2008, nr 6, s. 52.

48 A. Pieniążek, M. Stefaniuk, Socjologia prawa. Zarys wykładu, Warszawa 2014, s. 68; M. Weber, Gospodarka i społeczeństwo. Zarys socjologii rozumiejacej, Warszawa 2002, s. 6-7. M. Weber pisze, że w naukowych rozważaniach tworzących typy najbardziej przejrzystym sposobem badania i przedstawiania wszelkich irracjonalnych, afektywnie uwarunkowanych struktur sensownych zachowania, wpływających na działanie, jest traktowanie ich jako „odchyleń” od konstruktu jego czysto celowo-racjonalnego przebiegu. Gdy chcemy zatem zdefiniować zachowanie jako „nieskazitelne”, należałoby stwierdzić, jak przebiegałoby działanie, gdyby nie wpływały na nie irracjonalne afekty, a potem uwzględnić owe irracjonalne czynniki jako „zakłócenia nieskazitelności”. 
charakteru i w oparciu o ten model poszukiwać odniesień do wartości w ustawach korporacyjnych, orzecznictwie sądów, literaturze, ale też we własnej intuicji, jako że mimo braku definicji legalnej pojęcie nieskazitelności nie jest puste ${ }^{49}$. W wyroku z dnia 23 lutego 1999 r. Naczelny Sąd Administracyjny wskazał, że przesłanka wymieniona w art. 65 ust. 1 ustawy - Prawo o adwokaturze ma charakter uznaniowy. Sądowa kontrola decyzji uznaniowych cechuje się natomiast ograniczonym zakresem, sprowadzając się do ustalenia, czy decyzja (uchwała) została podjęta przez uprawniony do tego organ w przepisany sposób, czy przepisy prawa materialnego pozwalały na podjęcie takiej decyzji i czy badane rozstrzygnięcie nie nosi cech dowolności ${ }^{50}$. Inaczej w stosunku do radców prawnych kwestię tę potraktował Wojewódzki Sąd Administracyjny w Warszawie w wyroku z dnia 19 czerwca 2008 r., w którym stwierdził, że norma prawna zawarta w art. 24 ust. 1 pkt 5 ustawy o radcach prawnych zawiera kryteria ocenne, gdyż ma w swojej treści pojęcia niedookreślone (,nieskazitelny charakter”, „rękojmia prawidłowego wykonywania zawodu"). Jak wynika z powyższego, ustawodawca pozostawił organom samorządu radcowskiego margines swobodnej oceny w zakresie okoliczności świadczących o cechach indywidualnych zainteresowanego, ale nie oznacza to pozostawienia pola dla dowolności w zakresie ferowania takiej oceny ${ }^{51}$.

Nie można również przyjąć formalnego znaczenia „nieskazitelnego charakteru" w postaci zgodności danego postępowania z prawem bądź nie, gdyż w takiej sytuacji dostarczenie informacji o niekaralności z Krajowego Rejestru Karnego zgodnie z art. 68 ust. 3 pkt 1 ustawy - Prawo o adwokaturze i z art. 24 ust. 2a pkt 1 ustawy o radcach prawnych wystarczałoby do stwierdzenia istnienia ,nieskazitelnego charakteru" kandydata na adwokata bądź radcę prawnego. Takie stanowi-

49 W literaturze teoretycznoprawnej podnosi się, że prawnicy zawsze dostrzegali wpływ, jaki na pozornie racjonalne i dedukcyjne rozumowania prawnicze wywierają różnego rodzaju intuicje czy przeświadczenia. Decyzje osób decydujących o przymiocie nieskazitelności mogą być efektem subiektywnej reakcji na sprawę i wywołanego przez nią intuicyjnego przebłysku rozumienia pozwalającego dostrzec, po której stronie jest racja. Dopiero następczo podlega ona obudowaniu odpowiednimi argumentami prawnymi mającymi dostarczyć jej uzasadnienia. Zob. T. Pietrzykowski, Intuicja w myśleniu prawniczym, „Kwartalnik Okręgowej Izby Radców Prawnych w Katowicach” 2015, nr 3 (7), s. 22-23.

50 Wyrok NSA z dnia 23 lutego 1999 r., sygn. II SA 1888/98, LEX nr 46707.

51 Wyrok WSA z dnia 19 czerwca 2008 r., sygn. VI SA/Wa 849/08, LEX nr 491338. W literaturze podkreśla się, że uznania administracyjnego nie można utożsamiać z pojęciami niedookreślonymi. Gdy idzie o to pierwsze, to organ administrujący ma możliwość kształtowania sytuacji prawnej adresata normy za pośrednictwem aktu administracyjnego i obydwa rozwiązania - tak wpis, jak i odmowa wpisu - są dopuszczane przez ustawę i prawnie równowartościowe. $Z$ kolei użycie W normie prawnej pojęć niedookreślonych (nieostrych) implikuje konieczność dokonania wykładni takiego pojęcia w odniesieniu do konkretnej sprawy. W takim przypadku organ administrujący w istocie może podjąć tylko jeden rodzaj rozstrzygnięcia, który mógłby być uznany za prawidłowy. Zob. W. Studziński, Rękojmia należytego wykonywania zawodu adwokata w świetle orzecznictwa sąów administracyjnych i zmian ustawodawczych, „Palestra” 2010, nr 5/6, s. 84. 
sko reprezentują także sądy administracyjne. W wyroku z dnia 10 października 1986 r. Naczelny Sąd Administracyjny stwierdził, że nieskazitelność charakteru to nie tylko kwestia niekaralności czy niepopełnienia przestępstwa, to nie tylko ocena danej osoby w kategorii prawnej, lecz przede wszystkim jest to sfera etyczno-moralna. Chodzi tu więc nie o to, czy dana osoba popełniła przestępstwo, ponieważ to jest czyn zagrożony karą w ustawie karnej, lecz o to, czy osoba ta w dotychczasowym postępowaniu podejmowała i wykonywała działania obiektywnie oceniane jako naganne pod względem etyczno-moralnym, że w określonej sytuacji osoba ta nie powinna ze względów uczciwości i rzetelności, wzmożonych rodzajem posiadanego wykształcenia, charakteru wykonywanego zawodu, pełnionej służby i zajmowanego stanowiska, postąpić tak, jak uczyniła. Przedawnienie ścigania jako kategoria wyłącznie prawna, wykluczająca możliwość pociągnięcia danej osoby do odpowiedzialności karnej, karno-administracyjnej czy dyscyplinarnej, nie wyłącza zatem brania pod uwagę tego zachowania przy ocenie etyczno-moralnej jej sylwetki, w tym dokonywanej pod kątem przesłanki nieskazitelnego charakteru z art. 65 pkt 1 ustawy - Prawo o adwokaturze ${ }^{52}$.

W doktrynie podkreśla się, że nieskazitelny charakter to zwrot niedookreślony, który jest stosowany przez ustawodawcę wtedy, gdy zamierza on obdarzyć organ podejmujący decyzje pewną swobodą, elastycznością pozwalającą zastosować normę zawierającą zwrot niedookreślony w najróżniejszych sytuacjach, niemożliwych do wymienienia w przepisie, a nawet do przewidzenia ${ }^{53}$. Podkreśla się również, że w sytuacji, gdy termin „charakter” opatruje się wartościującymi przymiotnikami, a jednym z nich jest przymiotnik ,nieskazitelny”, to oznacza, że dany charakter jest bez zarzutu, nienaganny, bez skazy moralnej. W słownikowym znaczeniu człowiek obdarzony nienagannym charakterem to człowiek wielkiej prawości, zacny, kryształowy. Nieskazitelny to inaczej nieposzlakowany, szlachetny, prawy i uczciwy. Nieposzlakowany zaś to taki, któremu nic nie można zarzucić pod względem moralnym, nienaganny, nieskazitelny, doskonały. Tak rozumiejąc termin „nieskazitelny charakter”, można się pokusić o nakreślenie idealnego wzorca sędziego społecznego, który w rzeczywistości nie jest zbyt często osiągany, niemniej jest pomocny przy rozpatrywaniu konkretnych przypadków jako punkt odniesienia ${ }^{54}$.

Próbując określić katalog cech, jakie musi spełnić kandydat na adwokata i radcę prawnego, należy wskazać wzorzec, ideał, który wprawdzie nie jest osiągany, ale tworzy się go jako punkt odniesienia przy rozpatrywaniu konkretnych stanów faktycznych. Jak wspomniano wyżej, powinno się odrzucić przy podej-

52 Wyrok NSA z dnia 10 października 1986 r., sygn. IV SA 79/86, http://orzeczenia.nsa.gov. pl/doc/674D23AF37 [dostęp: 12.05.2016].

53 M. Zieliński, Wykładnia prawa. Zasady. Reguły. Wskazówki, Warszawa 2002, s. 170.

${ }_{54}$ M. Laskowski, op. cit., s. 52. 
mowaniu decyzji sądy wartościujące na rzecz odniesienia do wartości. Takim odniesieniem w praktyce może być ustawowy katalog cech wynikających z roty ślubowania, która jest podstawą zasad etyki zawodowej oraz orzecznictwa sądów powszechnych i administracyjnych. Zgodnie z art. 5 ustawy - Prawo o adwokaturze adwokat przed rozpoczęciem wykonywania czynności zawodowych składa wobec dziekana ślubowanie następującej treści: „Ślubuję uroczyście w swej pracy adwokata przyczyniać się ze wszystkich sił do ochrony praw i wolności obywatelskich oraz umacniania porządku prawnego Rzeczypospolitej Polskiej, obowiązki swe wypełniać gorliwie, sumiennie i zgodnie z przepisami prawa, zachować tajemnicę zawodową, a w postępowaniu swoim kierować się zasadami godności, uczciwości, słuszności i sprawiedliwości społecznej”. Zgodnie z art. 27 ust. 1 ustawy o radcach prawnych rota ślubowania składanego przez radcę prawnego ma następujące brzmienie: „Ślubuję uroczyście w wykonywaniu zawodu radcy prawnego przyczyniać się do ochrony i umacniania porządku prawnego Rzeczypospolitej Polskiej, obowiązki zawodowe wypełniać sumiennie i zgodnie z przepisami prawa, zachować tajemnicę zawodową, postępować godnie i uczciwie, kierując się zasadami etyki radcy prawnego i sprawiedliwości”.

Treść pojęcia nieskazitelnego charakteru na potrzeby konkretnego rozstrzygnięcia może wynikać z orzecznictwa sądów administracyjnych. Naczelny Sąd Administracyjny w wyroku z dnia 18 listopada 1999 r. stwierdził, że przez pojęcie nieskazitelności charakteru należy rozumieć całokształt cech indywidualnych, zdarzeń i okoliczności składających się na wizerunek notariusza jako osoby zaufania publicznego (podobnie sędziego, prokuratora, radcy prawnego, adwokata). Nie bez znaczenia dla ukazania tego wizerunku są fakty i zdarzenia ze sfery życia pozazawodowego, które podważałyby pozytywną ocenę postawy moralno-etycznej, naganne z punktu widzenia opinii publicznej, zasługujące na powszechne potępienie, uznane jako uchybienie godności nie zawsze skutkujące odpowiedzialnością dyscyplinarną, przy czym konieczne jest przeprowadzenie linii demarkacyjnej między sferą życia prywatnego i rodzinnego z życiem osobistym podlegającym ochronie zgodnie z art. 47 Konstytucji RP, a niewłaściwym zachowaniem i postawą względem innych osób świadczących o lekceważeniu norm moralnych i społecznych oraz zasad współżycia społecznego ${ }^{55}$. Jak podniósł Naczelny Sąd Administracyjny w wyroku z dnia 5 kwietnia 2001 r., na rękojmię w rozumieniu art. 65 prawa o adwokaturze składają się dwa elementy: cechy charakteru i dotychczasowe zachowanie osoby pragnącej zostać adwokatem. Wyrażenie ustawowe ,dotychczasowe zachowanie” oznacza postępowanie osoby ubiegającej się o wpis na listę adwokacką do czasu wpisania na tę listę, które,

55 Wyrok WSA w Warszawie z dnia 8 września 2006 r., sygn. VI SA/ Wa 1045/06, www. orzeczenia-nsa.pl/wyrok/vi-sa-wa-1045-06/adwokaci_i_aplikanci_adwokaccy/216aa07.html [dostęp: 14.05.2016]. 
odpowiadając ocenom moralnym i etycznym, gwarantuje właściwe wykonywanie zawodu adwokata ${ }^{56}$. Z kolei w wyroku Naczelnego Sądu Administracyjnego z dnia 18 czerwca 2001 r. sąd wskazał, iż zgodnie z art. 65 ust. 1 ustawy - Prawo o adwokaturze $\mathrm{w}$ toku postępowania o wpis na listę adwokatów ocenie winno podlegać postępowanie i zachowanie osoby ubiegającej się o wpis zarówno w sferze zawodowej, jak i prywatnej w dłuższym okresie czasu, przy czym o posiadaniu przymiotów ujętych w cytowanym przepisie mogą świadczyć między innymi opinie i okresy dotychczasowego zatrudnienia. Ponadto sąd uznał, że przez nieskazitelność należy rozumieć takie cechy charakteru, jak szlachetność, prawość, uczciwość. Są to cechy wartościujące konkretną osobę nie w sferze intelektualnej i profesjonalnej, lecz wyłącznie etyczno-moralnej ${ }^{57}$.

Analizując nieskazitelność charakteru adwokata i radcy prawnego, należy się odnieść również do pojęcia nieskazitelności wewnętrznej (materialnej) i zewnętrznej (formalnej). Nieskazitelność wewnętrzna będzie związana z typem osobowości i wyznawanymi wartościami kandydata na adwokata czy radcę prawnego ${ }^{58}$. Element wewnętrzny jest związany z godnością i zawiera się w pytaniu, jakie są pobudki działania kandydata na adwokata i radcę prawnego i co wpływa na jego postawę. Ten aspekt jest bardzo trudny do ustalenia, ponieważ sfera, która nie ujawni się na zewnątrz, nie podlega ocenie ${ }^{59}$. Wewnętrzna nieskazitelność charakteru związana jest zatem z normami społecznymi (prawem, moralnością, obyczajami, zwyczajami). Kandydat na radcę prawnego albo chce mieć nieskazitelny charakter, czyli zachowuje się zgodnie z prawem, dobrze, należycie, tak jak wypada, albo nie i wtedy zachowuje się niegodnie. Nieskazitelność charakteru ma wymiar zewnętrzny (formalny), gdy można postawę i zachowanie zewnętrze kandydata na adwokata bądź radcę ocenić i postawić zarzut, że zachował się niegodnie. To jest zachowanie zewnętrznie uchwytne. Naczelny Sąd Administracyjny w wyroku z dnia 18 listopada 1999 r. stwierdził, że nieskazitelny charakter to całokształt cech indywidualnych, zdarzeń i okoliczności składających się na wizerunek osoby zaufania publicznego. Ponadto orzekł, że nie bez znaczenia dla tego wizerunku są fakty i zdarzenia ze sfery życia pozazawodowego, które pod-

56 Wyrok NSA z dnia 5 kwietnia 2001 r., sygn. II SA 725/00, LEX nr 53476.

57 Wyrok NSA z dnia 18 czerwca 2001 r., sygn. II SA 1610/00, www.lexlege.pl/orzeczenie/155341/ii-sa-1610-00-wyrok-naczelnego-sadu-administracyjnego [dostęp: 16.05.2016].

58 Osobowość definiuje się jako zbiór unikalnych i stosunkowo trwałych cech indywidualnych jednostki, wyrażających jej tożsamość, ukształtowanych w procesie jej biologicznego, psychicznego i społecznego rozwoju przez bliższe i dalsze środowisko społeczne oraz przez jej własną aktywność poznawczą. Osobowość tworzą między innnymi zdolności, zainteresowania, postawy, poglądy, potrzeby, motywacje, wartości, temperament itp. Zob. K. Olechnicki, P. Załęcki, Słownik socjologiczny, Toruń 2002, s. 147.

59 Człowiek ma godność, gdy akceptuje i może afirmować siebie i innych oraz gdy inni akceptują i mogą afirmować jego. Zob. L. Ostasz, Dobre, złe, odpowiedzialne, sprawiedliwe... Definicje i objaśnienia pojęć etyki, Warszawa 2010, s. 34. 
ważyłyby pozytywną ocenę postawy moralno-etycznej, naganne z punktu widzenia opinii publicznej, uznane jako uchybienie godności nie zawsze skutkujące odpowiedzialnością dyscyplinarną ${ }^{60}$. Z kolei w wyroku z dnia 14 października 1991 r. Naczelny Sąd Administracyjny stwierdził, że przy ocenie dotychczasowego zachowania osoby ubiegającej się o wpis na listę radców prawnych bierze się pod uwagę takie kryteria, jak: szlachetność, prawość, uczciwość, przestrzeganie zasad etycznych. Powyższe elementy są punktem wyjścia do prognozowania jej zachowań jako radcy prawnego przy wykonywaniu obsługi prawnej w zakresie objętym art. 2 ustawy o radcach prawnych ${ }^{61}$.

Kolejnym aspektem rozumienia nieskazitelności charakteru jest nieskazitelność uprzednia (związana ze sposobem wejścia kandydata do zawodu adwokata i radcy prawnego) i następcza (związana z odpowiedzialnością dyscyplinarną adwokata i radcy prawnego). Samorząd zawodowy adwokatów i odpowiednio radców prawnych zgodnie z prawem wykonuje funkcje administracji publicznej przez pieczę nad zawodem adwokata i radcy prawnego oraz funkcje na rzecz swoich członków - najlepiej, najefektywniej reprezentuje członków samorządu. Piecza nad należytym wykonywaniem zawodów prawniczych jako zawodów zaufania publicznego powinna być realizowana jedynie w granicach interesu publicznego i dla jego ochrony. Interesem publicznym, którego powinny strzec prawnicze samorządy zawodowe, jest oczywiście odpowiednio wysoki poziom świadczonej przez prawników pomocy prawnej, mającej na celu ochronę prawną interesów podmiotów, na których rzecz jest wykonywana. Piecza może polegać również na: uprawnieniu do przyznawania prawa wykonywania zawodu, czyli pewnej formy reglamentacji dostępu do zawodu (nieskazitelność uprzednia); sprawowaniu sądownictwa dyscyplinarnego, czyli na uprawnieniu do pozbawienia prawa wykonywania zawodu (nieskazitelność następcza); sprawowaniu nadzoru nad sposobem wykonywania zawodu oraz na kształtowaniu zasad etyki i deontologii zawodowej. Państwo, oddając w ręce samorządu pieczę nad wykonywaniem zawodu, obdarzyło samorząd zaufaniem opartym na profesjonalnej wiedzy i doświadczeniu, które pozwala samorządom stanowić przepisy samorządowe (wewnętrznie obowiązujące). W celu wykonywania zadań prawnicze samorządy zawodowe stanowią akty normatywne (procedury działania), które zapewniają wykonywanie zadań własnych i zadań publicznych ${ }^{62}$. Po uznaniu, że dana osoba ma nieskazitelny charakter i po dopuszczeniu jej do wykonywania zawodu adwokata i radcy prawnego, dalsze oceny charakteru tej osoby pozostają w gestii organów zajmu-

60 Wyrok NSA z dnia 18 listopada 1999 r., sygn. II SA 1131/99, LEX nr 46696.

${ }^{61}$ Wyrok NSA z dnia 14 października 1991 r., sygn. II SA 559/91, „Radca Prawny” 1994, nr 6, s. 18.

62 S. Pilipiec, Prawo wewnętrznie obowiazujace stanowione przez organy prawniczych samorzadów zawodowych, [w:] Filozoficzne i teoretyczne zagadnienia demokratycznego państwa prawa, red. M. Andruszkiewicz, A. Breczko, S. Oliwniak, Białystok 2015, s. 362. 
jących się postępowaniem dyscyplinarnym (rzecznika dyscyplinarnego i sądów dyscyplinarnych) w przypadku naruszenia zasad etyki zawodowej (popełnienia deliktu dyscyplinarnego) i mogą być podważone jedynie w toku postępowania dyscyplinarnego ${ }^{63}$. Co więcej, w doktrynie pojawiają się głosy, że adwokaci i odpowiednio radcowie prawni wykorzystują postępowanie dyscyplinarne jako pole do konfrontacji zawodowej. Wykazują swój profesjonalizm przez wskazywanie i odróżnianie się od tych kolegów, którzy w swej pracy nie wykazują pożądanych predyspozycji etycznych, czyli nie posiadają nieskazitelnego charakteru. Należy zatem spodziewać się umieszczania na stronach internetowych kancelarii prawniczych informacji o braku postępowań dyscyplinarnych toczących się względem adwokatów czy radców prawnych ${ }^{64}$.

Z ustawy - Prawo o adwokaturze i ustawy o radcach prawnych wynika, że łącznie z posiadaniem nieskazitelnego charakteru kandydat na adwokata i radcę prawnego powinien dawać rękojmię prawidłowego wykonywania zawodu. Z orzecznictwa sądów administracyjnych wynika, że nie chodzi jednak tylko o intelektualne, merytoryczne i fachowe kwalifikacje adwokatów i radców prawnych. Przez rękojmię należy rozumieć taki zespół cech osobistych, charakteru i zachowań składających się na wizerunek osoby zaufania publicznego, na której nie ciążą żadne zarzuty podważające jej wiarygodnośćc5. Przesłanka rękojmiowa ma służyć dokonaniu przez samorządowe organy adwokatów oceny kandydata pod kątem jego walorów etyczno-moralnych i na tej podstawie postawieniu prognozy, czy będzie on prawidłowo wykonywał zawód. W tym sensie jest więc wspomnia-

${ }_{63}$ Radcowie prawni i adwokaci podlegają odpowiedzialności dyscyplinarnej za postępowanie sprzeczne z prawem, zasadami etyki lub godnością zawodu bądź za naruszenie swych obowiązków zawodowych (art. 80 ustawy - Prawo o adwokaturze i art. 64 ustawy o radcach prawnych). Karą dyscyplinarną orzeczoną przez sąd dyscyplinarny w toku postępowania dyscyplinarnego może być kara wydalenia z adwokatury (art. 81 ust. 1 ustawy - Prawo o adwokaturze) lub kara pozbawienia prawa do wykonywania zawodu radcy prawnego (art. 65 ust. 1 pkt 5). W przypadku obu zawodów o ponowny wpis na listę adwokatów bądź radców prawnych można ubiegać się po 10 latach od dnia uprawomocnienia się kary (art. 82 ust. 2 ustawy - Prawo o adwokaturze i art. 65 ust. 2c ustawy o radcach prawnych). Jednakże usunięcie wzmianki o ukaraniu dyscyplinarnym następuje z urzędu po upływie: 15 lat w stosunku do adwokata od dnia uprawomocnienia się orzeczenia dyscyplinarnego orzekającego karę wydalenia z adwokatury (art. $95 \nmid$ ust. 4 pkt 3 ustawy - Prawo o adwokaturze) oraz 15 lat od uprawomocnienia się orzeczenia dyscyplinarnego orzekającego karę pozbawienia prawa do wykonywania zawodu radcy prawnego (art. 71 ust. 5 pkt 3 ustawy o radcach prawnych). Mimo że adwokat lub radca prawny może ubiegać się o wpis na listę adwokatów lub radców prawnych po 10 latach, może mieć zatem problem z wykazaniem się cechą nieskazitelności charakteru do czasu usunięcia wzmianki o ukaraniu, czyli jeszcze przez pięć lat. Co więcej, jak wskazano w pierwszej części artykułu, problemem może też być swoista „odnawialność” cechy nieskazitelności charakteru po upływie stosownego czasu w przypadku usunięcia z zawodu.

64 Z. Gintowt, Głos $w$ dyskusji pt. ,Rola samorząów prawniczych $w$ ksztaltowaniu etyki zawodowej”, [w:] Wartości a sukces zawodowy prawników - granice kompromisu?, red. E. Łojko, M. Dziurnikowska-Stefańska, Warszawa 2011, s. 34-35.

65 M. Laskowski, op. cit., s. 63. 
ny „wentyl bezpieczeństwa” niezbędny dla zapewnienia dostępu do zawodu osób, które poza wysokim poziomem przygotowania merytorycznego do świadczenia pomocy prawnej dają - właśnie swym nieskazitelnym charakterem i dotychczasowym zachowaniem - rękojmię należytego wykonywania zawodu. Jest to przesłanka o znaczeniu fundamentalnym dla zapewnienia właściwej jakości i poziomu świadczonej pomocy prawnej ${ }^{66}$. Posiadanie nieskazitelnego charakteru daje rękojmię prawidłowego wykonywania zawodu, natomiast brak rękojmi implikuje brak nieskazitelnego charakteru.

Na koniec należy podkreślić, że z praktyki dokonywanej przez organy samorządów zawodowych adwokatów i radców prawnych wynika, iż przy ocenie nieskazitelności charakteru kandydata na adwokata czy radcę prawnego uwzględnia się domniemanie, że kandydat posiada cechę nieskazitelnego charakteru i tylko w drodze dowodzenia (uwzględniając dane o karalności, informacje od policji, inne informacje poddane weryfikacji, np. referencje, rekomendacje) można obalić takie domniemanie. Zgodnie z orzeczeniem Trybunału Konstytucyjnego z dnia 7 maja 2002 r. kryteria dotyczące nieskazitelności charakteru nie mogą być nadużywane w celu ograniczenia dostępu do zawodu adwokata i radcy prawnego ${ }^{67}$.

\section{BIBLIOGRAFIA}

Bodio J., „Nieskazitelność charakteru” jako kwalifikacja zawodowa sędziego (wptywająca na jego wizerunek), „Kwartalnik Krajowej Szkoły Sądownictwa i Prokuratury” 2013, nr 4.

Borkowski G., Nieskazitelność charakteru a powołanie do wykonywania zawodów prawniczych, [w:] Etyka zawodów prawniczych w praktyce. Wzajemne relacje i oczekiwania, red. G. Borkowski, Lublin 2012.

Dąbrowski S., Łazarska A., Dział II. Sędziowie, [w:] Prawo o ustroju sądów powszechnych. Komentarz LEX, red. A. Górski, Warszawa 2013.

Gintowt Z., Głos $w$ dyskusji pt. „Rola samorzadów prawniczych $w$ ksztaltowaniu etyki zawodowej”, [w:] Wartości a sukces zawodowy prawników - granice kompromisu?, red. E. Łojko, M. Dziurnikowska-Stefańska, Warszawa 2011.

Gromski W., Klauzule generalne, [w:] Wprowadzenie do nauk prawnych. Leksykon tematyczny, red. A. Bator, Warszawa 2010.

Grzonka L., Kostrubiec J., Zawód zaufania publicznego. Przyczynek do dyskusji, „Studia Iuridica Lublinensia" 2007, nr 9.

Kaczmarek P., Rzady prawa a sprawcze wykonywanie zawodu radcy prawnego, „Radca Prawny” 2015, nr 1 (2).

Klatka Z., Wykonywanie zawodu radcy prawnego i adwokata, Warszawa 2004.

Kodeks etyki zawodowej komornika sądowego (t.j. opublikowany uchwałą KRK nr 909/IV z dnia 8 lutego 2012 r.), www.komornik.pl/wp-content/uploads/2015/05/kezktj.pdf [dostęp: 15.04.2016].

Konarska-Wrzosek V., Odpowiedzialność karna komornika sądowego, „Przegląd Prawa Egzekucyjnego" 2006, nr 12.

66 W. Studziński, op. cit., s. 84.

67 Wyrok TK z dnia 7 maja 2002 r., sygn. SK 20/00, OTK-A 2002, nr 3, poz. 29. 
Laskowski M., Ustawowe pojęcie „,nieskazitelność charakteru”, „Prokuratura i Prawo” 2008, nr 6. Ławnikowicz G., Idea niezawistości sędziowskiej w porządku prawnym i myśli prawniczej II RP, Toruń 2009.

Olechnicki K., Załęcki P., Stownik socjologiczny, Toruń 2002.

Orzeczenie SN z dnia 12 czerwca 2003 r., SNO 29/03, www.sn.pl/orzecznictwo/SitePages/Baza_ orzeczen.aspx? Sygnatura $=$ sno $\% 2029 / 03$ [dostęp: 11.06.2016].

Orzeczenie SN z dnia 17 kwietnia 2007 r., SNO 20/07, www.sn.pl/orzecznictwo/SitePages/Baza orzeczen.aspx?Sygnatura $=$ sno $\% 2020 / 07$ [dostęp: 11.06.2016]

Orzeczenie SN z dnia 20 września 2007 r., SNO 60/07, www.sn.pl/orzecznictwo/SitePages/Baza_ orzeczen.aspx?Sygnatura $=\mathrm{sno} \% 2060 / 07$ [dostęp: 12.06.2016].

Orzeczenie SN z dnia 27 czerwca 2008 r., SNO 51/08, www.sn.pl/orzecznictwo/SitePages/Baza orzeczen.aspx? Sygnatura $=$ sno $\% 2051 / 08$ [dostęp: 12.06.2016].

Orzeczenie SN z dnia 12 marca 2009 r., SNO 9/09, www.sn.pl/orzecznictwo/SitePages/Baza_orzeczen.aspx?Sygnatura $=$ sno\%209/09 [dostęp: 12.06.2016].

Orzeczenie SN z dnia 20 czerwca 2013 r., SNO 8/13, www.sn.pl/orzecznictwo/SitePages/Baza orzeczen.aspx?Sygnatura $=$ sno\%208/13 [dostęp: 12.06.2016].

Orzeczenie WSA w Warszawie z dnia 21 grudnia 2009 r., VI SA/Wa 1719/09, http://orzeczenia.nsa. gov.pl [dostęp: 14.05.2016].

Ostasz L., Dobre, złe, odpowiedzialne, sprawiedliwe... Definicje i objaśnienia pojęć etyki, Warszawa 2010.

Pieniążek A., Stefaniuk M., Socjologia prawa. Zarys wykładu, Warszawa 2014.

Pietrzykowski T., Intuicja w myśleniu prawniczym, „Kwartalnik Okręgowej Izby Radców Prawnych w Katowicach" 2015, nr 3 (7).

Pilipiec S., Prawo wewnętrznie obowiazujace stanowione przez organy prawniczych samorzadów zawodowych, [w:] Filozoficzne i teoretyczne zagadnienia demokratycznego państwa prawa, red. M. Andruszkiewicz, A. Breczko, S. Oliwniak, Białystok 2015.

Postanowienie SN z dnia 12 czerwca 2003 r., SNO 29/03, www.sn.pl/orzecznictwo/SitePages/Baza orzeczen.aspx? Sygnatura $=$ sno\%2029/03 [dostęp: 10.06.2016].

Rozporządzenie Ministra Sprawiedliwości z dnia 21 marca 2012 r. w sprawie sporządzania informacji o kandydacie do objęcia stanowiska sędziowskiego (Dz.U. z 2012 r., poz. 332).

Studziński W., Rękojmia należytego wykonywania zawodu adwokata w świetle orzecznictwa sądów administracyjnych i zmian ustawodawczych, „Palestra” 2010, $\mathrm{nr}$ 5/6.

Tabaszewski K., Etyka i odpowiedzialność zawodowa adwokatów i radców prawnych jako przedsiębiorców, [w:] Człowiek - społeczeństwo - gospodarka. Perspektywa odpowiedzialności społecznej, red. A. Zadroga, K. Sawicki, Lublin 2013.

Uchwała SN z dnia 15 września 2004 r., SNO 34/04, www.sn.pl/orzecznictwo/SitePages/Baza_ orzeczen.aspx?Sygnatura $=$ sno $\% 2034 / 04$ [dostęp: 14.06.2016].

Uchwała SN z dnia 28 września 2004 r., SNO 35/04, www.sn.pl/orzecznictwo/SitePages/Baza orzeczen.aspx? Sygnatura $=$ sno $\% 2035 / 04$ [dostęp: 14.06.2016].

Uchwała SN z dnia 5 lipca 2006 r., SNO 32/06, www.sn.pl/orzecznictwo/SitePages/Baza_orzeczen. aspx? Sygnatura $=$ sno $\% 2032 / 06$ [dostęp: 14.06 .2016 ].

Uchwała SN z dnia 17 kwietnia 2007 r., SNO 20/07, www.sn.pl/orzecznictwo/SitePages/Baza_orzeczen.aspx?Sygnatura $=$ sno\%2020/07 [dostęp: 10.06.2016].

Uchwała SN z dnia 7 lipca 2009 r., SNO 17/09, www.sn.pl/orzecznictwo/SitePages/Baza_orzeczen. aspx? Sygnatura $=$ sno $\% 2017 / 09$ [dostęp: 10.06.2016].

Uchwała SN z dnia 15 grudnia 2011 r., SNO 46/11, www.sn.pl/orzecznictwo/SitePages/Baza_orzeczen.aspx?Sygnatura $=$ sno\%2046/11 [dostęp: 10.06.2016].

Ustawa z dnia 26 maja 1982 r. - Prawo o adwokaturze (t.j. Dz.U. z 2015 r., poz. 615).

Ustawa z dnia 6 lipca 1982 r. o radcach prawnych (t.j. Dz.U. z 2014 r., poz. 637, 993, 1778).

Ustawa z dnia 20 czerwca 1985 r. o prokuraturze (t.j. Dz.U. z 2002 r., nr 21, poz. 206). 
Ustawa z dnia 6 kwietnia 1990 r. o Policji (t.j. Dz.U. z 2011 r., nr 287, poz. 1687 z późn. zm.).

Ustawa z dnia 14 lutego 1991 r. - Prawo o notariacie (t.j. Dz.U. z 2014 r., poz. 164).

Ustawa z dnia 11 kwietnia 1997 r. o ujawnieniu pracy lub służby w organach bezpieczeństwa państwa lub współpracy z nimi w latach 1944-1990 osób pełniących funkcje publiczne (t.j. Dz.U. z 1999 r., nr 42, poz. 428).

Ustawa z dnia 21 sierpnia 1997 r. - Prawo o ustroju sądów wojskowych (Dz.U. z 2015 r., poz. 1198).

Ustawa z dnia 29 sierpnia 1997 r. o komornikach sądowych i egzekucji (t.j. Dz.U. z 2015 r., poz. 790).

Ustawa z dnia 18 grudnia 1998 r. o pracownikach sądów i prokuratury (t.j. Dz.U. z 2015 r., poz. 1241).

Ustawa z dnia 27 lipca 2001 r. - Prawo o ustroju sądów powszechnych (Dz.U. z 2001 r., nr 98, poz. 1070 z późn. zm.).

Ustawa z dnia 25 lipca 2002 r. - Prawo o ustroju sądów administracyjnych (t.j. Dz.U. z 2014 r., poz. 1647).

Ustawa z dnia 23 listopada 2002 r. o Sądzie Najwyższym (t.j. Dz.U. z 2013 r., poz. 499).

Ustawa z dnia 8 lipca 2005 r. o Prokuratorii Generalnej Skarbu Państwa (t.j. Dz.U. z 2013 r., poz. 1150).

Ustawa z dnia 24 maja 2007 r. o zmianie ustawy o komornikach sądowych i egzekucji oraz niektórych innych ustaw (Dz.U. z 2007 r., nr 112, poz. 769).

Ustawa z dnia 21 listopada 2008 r. o pracownikach samorządowych (t.j. Dz.U. z 2014 r., poz. 1202). Ustawa z dnia 21 listopada 2008 r. o służbie cywilnej (t.j. Dz.U. z 2014 r., poz. 111 z późn. zm.).

Weber M., Gospodarka i społeczeństwo. Zarys socjologii rozumiejącej, Warszawa 2002.

Wyrok NSA z dnia 10 października 1986 r., sygn. IV SA 79/86, http://orzeczenia.nsa.gov.pl/doc/674D23AF37 [dostęp: 12.05.2016].

Wyrok NSA z dnia 14 października 1991 r., sygn. II SA 559/91, „Radca Prawny” 1994, nr 6.

Wyrok NSA z dnia 23 lutego 1999 r., sygn. II SA 1888/98, LEX nr 46707.

Wyrok NSA z dnia 18 listopada 1999 r., sygn. II SA 1131/99, LEX nr 46696.

Wyrok NSA z dnia 5 kwietnia 2001 r., sygn. II SA 725/00, LEX nr 53476.

Wyrok NSA z dnia 18 czerwca 2001 r., sygn. II SA 1610/00, www.lexlege.pl/orzeczenie/155341/ ii-sa-1610-00-wyrok-naczelnego-sadu-administracyjnego [dostęp: 16.05.2016].

Wyrok SN z dnia 9 czerwca 2005 r., SNO 28/05, www.sn.pl/orzecznictwo/SitePages/Baza_orzeczen.aspx?Sygnatura $=$ sno\%2028/05 [dostęp: 10.06.2016].

Wyrok SN z dnia 21 października 2008 r., SNO 78/08, www.sn.pl/orzecznictwo/SitePages/Baza_ orzeczen.aspx?Sygnatura $=\mathrm{sno} \% 2078 / 08$ [dostęp: 10.06.2016].

Wyrok SN z dnia 15 czerwca 2011 r., SNO 25/11, www.sn.pl/orzecznictwo/SitePages/Baza_orzeczen.aspx?Sygnatura=sno\%2025/11 [dostęp: 14.06.2016].

Wyrok SN z dnia 26 maja 2014 r., SNO 20/14, www.sn.pl/orzecznictwo/SitePages/Baza_orzeczen. aspx?Sygnatura $=$ sno $\% 2020 / 14$ [dostęp: 10.06 .2016$]$.

Wyrok TK z dnia 7 maja 2002 r., sygn. SK 20/00, OTK-A 2002, nr 3, poz. 29

Wyrok TK z dnia 18 października 2010 r., sygn. K 1/09 (Dz.U. z 2010 r., nr 200, poz. 1326).

Wyrok WSA w Warszawie z dnia 8 września 2006 r., sygn. VI SA/ Wa 1045/06, www.orzeczenia-nsa.pl/ wyrok/vi-sa-wa-1045-06/adwokaci_i_aplikanci_adwokaccy/216aa07.html [dostęp: 14.05.2016].

Wyrok WSA z dnia 19 czerwca 2008 r., sygn. VI SA-Wa 849/08, LEX nr 491338.

Zawód radcy prawnego. Historia i zasady jego wykonywania, red. A. Bereza, Warszawa 2014.

Zieliński Z., Wykładnia prawa. Zasady. Reguły. Wskazówki, Warszawa 2002. 


\section{SUMMARY}

The article aims to decode the concepts of impeccable character and good repute in the law of legal professional self-governing bodies. The authors focus on answering a few specific questions, particularly including the following: 1) What is the position of clauses in the system of a given profession, and how do this position, and thus the relations to other obligations that are usually also in the form of clauses, affect the significance attributed to impeccable character and good repute? 2) What elements modify the content of clauses and what are the directions of those modifications? 3) Does the content of obligation vary depending on the profession (or, perhaps, within one profession) that the requirement concerns? What determines the possible differences? 4) To what extent does time act as a modifying element? This text, although based on an analysis of all primary sources of knowledge of the relevant subject (legal acts, including the codes of professional ethics, judicial decisions and the relevant literature), does not aspire to fully cover it. Realising the impossibility of a complex and thorough analysis, the authors decided to remain autonomous in selecting research methods and determining the role of specific fields of scientific exploration.

Keywords: immpeccable charakter; good repute; profession of public trust; judge; public prosecutor; notary; bailiff; barrister; legal counsel

\section{STRESZCZENIE}

Celem artykułu jest odkodowanie treści łączonych z pojęciami „nieskazitelność charakteru” $\mathrm{i}$, ,nieposzlakowana opinia” w prawie prawniczych samorządów zawodowych. Autorzy koncentrują się na ustaleniu odpowiedzi na kilka szczegółowych pytań, zwłaszcza: 1) Jakie jest usytuowanie klauzul w systemie danej profesji i jak ta pozycja, a tym samym relacje $\mathrm{z}$ innymi powinnościami, na ogół także ujętymi w formę klauzul, wpływa na znaczenie przypisywane nieskazitelności charakteru i nieposzlakowanej opinii? 2) Jakie elementy modyfikują treść klauzul i jakie są kierunki tych modyfikacji? 3) Czy treść powinności jest różna w zależności od profesji (i ewentualnie $\mathrm{w}$ ramach profesji), do której jest adresowany wymóg? Co warunkuje możliwe różnice? 4) W jakim stopniu rolę elementu modyfikującego odgrywa czas? Niniejsze opracowanie wprawdzie opiera się na analizie wszystkich podstawowych źródeł poznania tytułowej problematyki (akty prawne, w tym kodeksy etyki zawodowej, orzecznictwo i literatura tematu), nie aspiruje jednak do całościowego jej ujęcia. Zdając sobie sprawę z obiektywnej niemożności przeprowadzenia kompleksowej i wyczerpującej analizy, autorzy przyznali sobie szeroką autonomię w doborze metod badawczych i wyważeniu roli poszczególnych pól naukowej eksploracji.

Słowa kluczowe: nieskazitelność charakteru; nieposzlakowana opinia; zawód zaufania publicznego; sędzia; prokurator; notariusz; komornik 